Linköping University Medical Dissertation No. 1737

\title{
Clinical and immunological aspects on recurrent pregnancy loss
}



\section{Valentina Bruno}

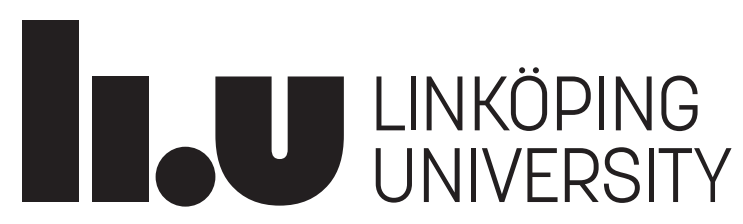


Linköping University Medical Dissertation No. 1737

\title{
Clinical and immunological aspects on recurrent pregnancy loss
}

\author{
Valentina Bruno
}

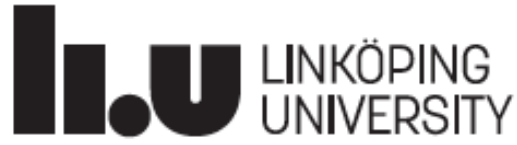

FACULTY OF MEDICINE AND HEALTH SCIENCES

Clinical Immunology \& Obstetrics and Gynecology

Department of Biomedical and Clinical Sciences (BKV)

Linköping University

SE-581 83 Linköping, Sweden

www.liu.se

Linköping 2020 


\section{Cover image}

Valentina Bruno, Giacomo Corrado, Denisa Baci, Benito Chiofalo, Maria Antonia Carosi, Livia Ronchetti, Emilio Piccione, Adriana Albini, Douglas M. Noonan, Giulia Piaggio and Enrico Vizza. Endometrial Cancer Immune Escape Mechanisms: Let Us Learn From the Fetal-Maternal Interface. Frontiers in Oncology | www.frontiersin.org; February 2020 | Volume 10 | Article 156

\section{Published Paper copyright}

Paper I (c) Springer Nature Research

Paper II (C) Springer Nature Research

Linköping University Medical Dissertation No. 1737

ISBN: 978-91-7929-861-6

ISSN: 0345-0082

Printed by LiU-tryck, Linköping, Sweden, 2020 
"To be creative, scientists need libraries and laboratories and the company of other scientists" - Sir Peter B. Medawar 


\section{Supervisor}

Professor Jan Ernerudh, Linköping University, Sweden

\section{Co-Supervisors}

Professor Maria Jenmalm, Linköping University, Sweden

Professor Emilio Piccione, Tor Vergata University, Rome

Professor Adalgisa Pietropolli, Tor Vergata University, Rome

Professor Carlo Ticconi, Tor Vergata University, Rome

\section{Faculty Opponent}

Professor Udo R. Markert, Jena University, Germany 


\section{TABLE OF CONTENTS}

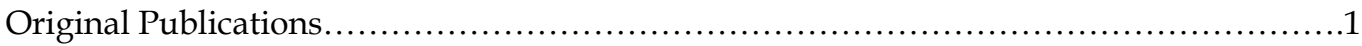

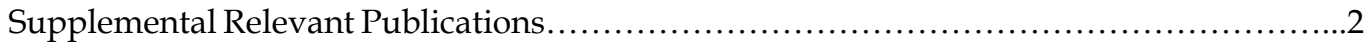

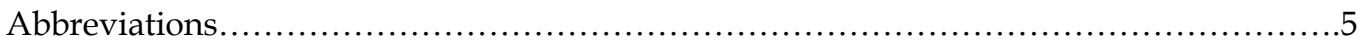

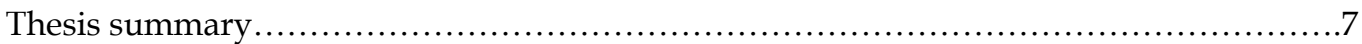



\section{Introduction}

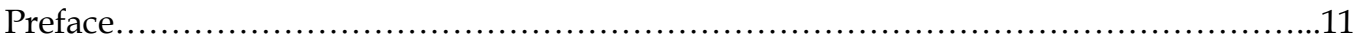

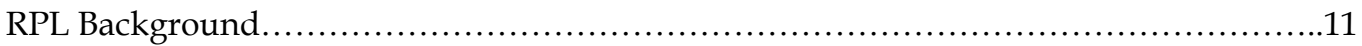

Evolution in definition and its clinical implications in prognosis.....................11



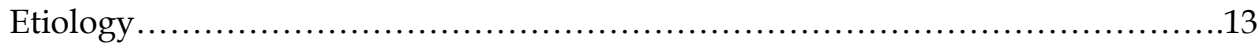

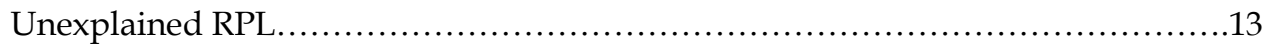

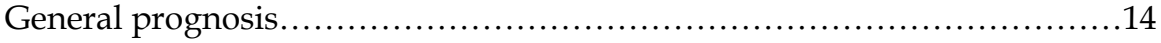

Potential therapeutical approaches in uRPL.................................15

Heparin structure and its interactions.................................15

Known immunological effects of Low Molecular Weight Heparin......16

Immune tolerance establishment in physiological and uRPL pregnancies....................17

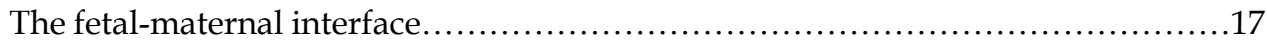

Interplay between the immune and angiogenesis stimuli during pregnancy.........18

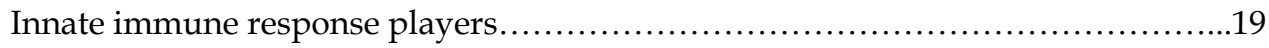

Natural killer cells.............................................................

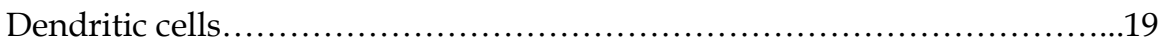

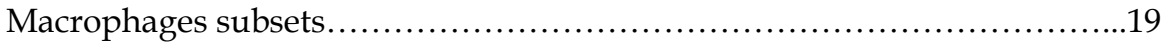

Myeloid-derived suppressor cells (MDSCs) .................................20

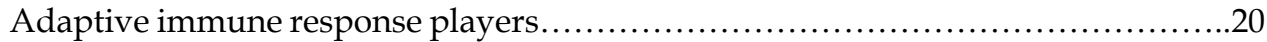

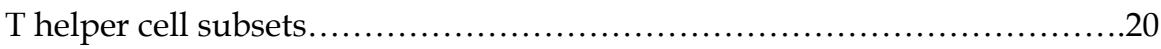

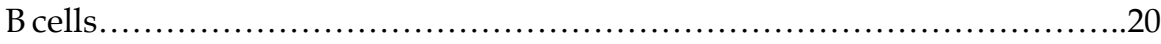


Cytokines and chemokines...............................................21



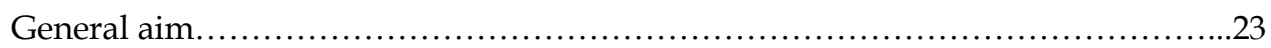

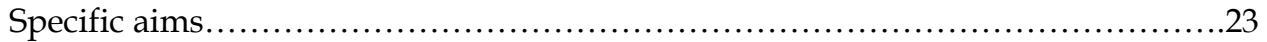







Subjects, ethical aspects and settings.......................................... 24

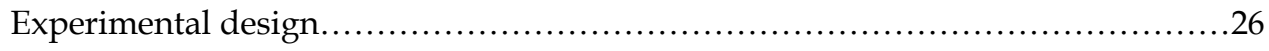

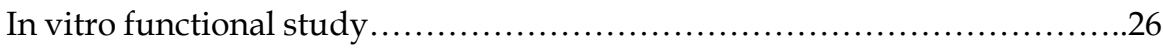

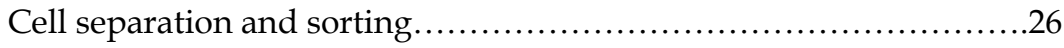

Macrophage polarization model principles.........................27

Flow Cytometry analysis of surface and intracellular markers expression..................................................27

Luminex analysis for cytokines and chemokines production..........28





Proteomic assays........................................................ 29

Statistical Methods..........................................................

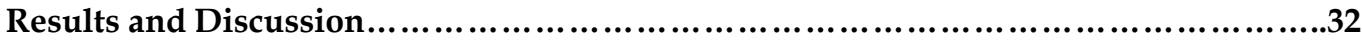

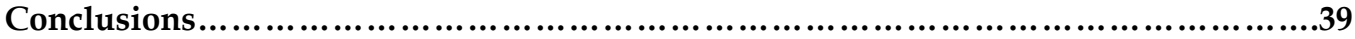

Future directions...............................................................40

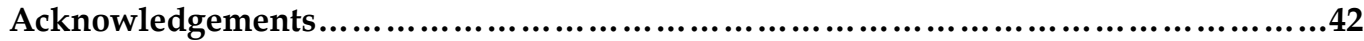

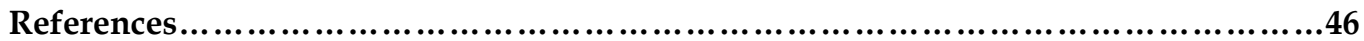




\section{Original pubblications}

Paper I: *V Bruno, * J Svensson-Arvelund, M Rubér, G Berg, E Piccione, MC Jenmalm, J Ernerudh. ( ${ }^{*}$ These authors contributed equally). Effects of low molecular weight heparin on the polarization and cytokine profile of macrophages and $\mathrm{T}$ helper cells in vitro. Sci Rep. 2018;8:4166.

Paper II: *Rasmark Roepke E, *Bruno V, Nedstrand, E. Boij, R, Strid, CP, Piccione, E, Berg, G, Svensson Arvelund, J, Jenmalm, MC, ${ }^{*}$ Rubér, M, ${ }^{*}$ Ernerudh, J. (*These authors contributed equally). Low-molecular-weight-heparin increases Th1- and Th17-associated chemokine levels during pregnancy in women with unexplained recurrent pregnancy loss: a randomised controlled trial. Sci Rep. 2019:9;12314

Paper III: Bruno V, Lindau R, Jenmalm MC, Ticconi C, Piccione E, *Pietropolli A, *Ernerudh J. ( ${ }^{*}$ These authors contributed equally) First-trimester trophoblasts obtained by chorionic villus sampling maintain tolerogenic and proteomic features in successful pregnancies despite a history of unexplained recurrent pregnancy loss. Am J Reprod Immunol. E-pub ahead of print $2020 \mathrm{Jul}$ 30:e13314. 


\section{Supplemental Relevant Publications}

1.Pietropolli A, Giuliani E, Bruno V, Patrizi L, Piccione E, Ticconi C. Plasminogen activator inhibitor-1, factor $\mathrm{V}$, factor II and methylenetetrahydrofolate reductase polymorphisms in women with recurrent miscarriage. J Obstet Gynaecol. 2014;3:229-34.

2.Veglia M, D'Ippolito S, Marana R, Di Nicuolo F, Castellani R, Bruno V, Fiorelli A, Ria F, Maulucci G, De Spirito M, Migliara G, Scambia G, Di Simone N. Human IgG Antinuclear Antibodies Induce Pregnancy Loss in Mice by Increasing Immune Complex Deposition in Placental Tissue: In Vivo Study. Am J Reprod Immunol. 2015;74:542-52.

3.Pietropolli A, Bruno V, Capogna MV, Bernardini S, Piccione E, Ticconi C. Uterine blood flow indices, antinuclear autoantibodies and unexplained recurrent miscarriage. Obstet Gynecol Sci. 2015;58:453-60.

4.Pietropolli A, Capogna MV, Cascella R, Germani C, Bruno V, Strafella C, Sarta S, Ticconi C, Marmo G, Gallaro S, Longo G, Marsella LT, Novelli A, Novelli G, Piccione E, Giardina E. Three-hour analysis of non-invasive foetal sex determination: application of Plexor chemistry. Hum Genomics. 2016;10:9.

5.Ticconi C, Pietropolli A, Borelli B, Bruno V, Piccione E, Bernardini S, Di Simone N. Antinuclear autoantibodies and pregnancy outcome in women with unexplained recurrent miscarriage. Am J Reprod Immunol. 2016;76:396-399.

6.Bruno V, Rizzacasa B, Pietropolli A, Capogna MV, Massoud R, Ticconi C, Piccione E, Cortese C, Novelli G, Amati F. OLR1 and Loxin Expression in PBMCs of Women with a History of Unexplained Recurrent Miscarriage: A Pilot Study. Genet Test Mol Biomarkers. 2017;21:363-372.

7.Ticconi C, Capogna MV, Martelli F, Borelli B, Bruno V, Ergasti R, Sorge R, Piccione E, Pietropolli A. Ectopic pregnancy in women with recurrent miscarriage. J Obstet Gynaecol Res. 2018;44:852-860.

8.Bruno V, Martelli F, Capogna MV, Youssef A, Bruno A, Ticconi C, Piccione E, Pietropolli A. Effect of chorionic villus sampling on placental volume and vascularization in the first trimester of pregnancy. J Matern Fetal Neonatal Med. 2020;33:726-730.

9.Valentina Bruno, Carlo Ticconi, Simona Sarta, Emilio Piccione, Adalgisa Pietropolli. What has to be pointed out in unexplained recurrent pregnancy loss research in the unsolved fields : lessons from clinic. An Italian RPL Unit experience. It. J. Gynaecol. Obstet. 2019;31:2 
10. Bruno V, Nuccetelli M, Ticconi C, Bruno A, Martelli F, Capogna MV, Bernardini S, Piccione E, Pietropolli A. Amniotic fluid antiphospholipid antibodies: potential role in antiphospholipid syndrome-independent aberrant implantation process. Reprod Biol Endocrinol. 2019;17:79.

11.Martelli F, Youssef A, Capogna MV, Bruno A, Bruno V, Dodaro MG, Ticconi C, Ghi T, Piccione E, Pietropolli A. Longitudinal Changes of Subpubic Arch Angle throughout Pregnancy. Gynecol Obstet Invest. 2020;85:100-106.

12.Bruno V, Ticconi C, Martelli F, Nuccetelli M, Capogna MV, Sorge R, Piccione E, Pietropolli A. Uterine and placental blood flow indexes and antinuclear autoantibodies in unexplained recurrent pregnancy loss: should they be investigated in pregnancy as correlated potential factors? A retrospective study. BMC Pregnancy Childbirth. 2020;20:44.

13.Bruno V, Corrado G, Baci D, Chiofalo B, Carosi MA, Ronchetti L, Piccione E, Albini A, Noonan DM, Piaggio G, Vizza E. Endometrial Cancer Immune Escape Mechanisms: Let Us Learn From the Fetal-Maternal Interface. Front Oncol. 2020;10:156.

14.Vizza E, Cutillo G, Bruno V, Sperduti I, Mancini E, Baiocco E, Chiofalo B, Cicchillitti L, Certelli C, Zampa A, Piccione E, Corrado G. Pattern of recurrence in patients with endometrial cancer: A retrospective study. Eur J Surg Oncol. 2020;46:1697-1702.

15.Corrado G, Cutillo G, Fragomeni SM, Bruno V, Tagliaferri L, Mancini E, Certelli C, Paris I, Vizza E, Scambia G, Garganese G. Palliative electrochemotherapy in primary or recurrent vulvar cancer. Int J Gynecol Cancer. 2020;30:927-931.

16.Bruno V, D'Orazio M, Ticconi C, Abundo P, Riccio S, Martinelli E, Rosato N, Piccione E, Zupi E, Pietropolli A. Machine Learning (ML) based-method applied in recurrent pregnancy loss (RPL) patients diagnostic work-up: a potential innovation in common clinical practice. Sci Rep. 2020;10:7970.

17.Chiofalo B, Baiocco E, Mancini E, Vocaturo G, Cutillo G, Vincenzoni C, Bruni S, Bruno V, Mancari R, Vizza E. Practical recommendations for gynecologic surgery during the COVID-19 pandemic. Int J Gynaecol Obstet. 2020;150:146-150.

18.Vanni G, Pellicciaro M, Materazzo M, Bruno V, Oldani C, Pistolese CA, Buonomo C, Caspi J, Gualtieri P, Chiaravalloti A, Palombi L, Piccione E, Buonomo OC. Lockdown of Breast Cancer Screening for COVID-19: Possible Scenario. In Vivo. 2020;34:3047-3053.

19.Mancari R, Cutillo G, Bruno V, Vincenzoni C, Mancini E, Baiocco E, Bruni S, Vocaturo G, Chiofalo B, Vizza E. Development of new medical treatment for epithelial ovarian cancer recurrence. Gland Surg. 2020;9:1149-1163. 
20.Patrizi L, Borelli B, Di Prete M, Bruno V, Mauriello A, Piccione E, Ticconi C. A rare case of vulvar superficial myofibroblastoma associated with ambigous and unusual differential diagnosis. Gynecol Oncol Rep. 2020;34:100637.

21. Corrado G., Bruno V., Vizza E. When two genes do not work properly. Journal of Translational Science (article in press). 


\section{Abbreviations}

Acetylsalicylic acid (ASA)

American Society for Reproductive Medicine (ASRM)

Anti-Beta 2 Glycoprotein I (anti-ß2GPI)

Anticardiolipin antibodies (ACA)

Antinuclear antibody (ANA)

Antithyroid peroxidase (anti-TPO)

Artificial Intelligence (AI)

Chorionic villous sampling (CVS)

Conditioned medium (CM)

Decidual Natural killer cells (dNKs)

Decidual stromal cells (DSCs)

Dendritic cells (DCs)

Endometrial stromal cells (ESCs)

European Society of Human Reproduction and Embryology (ESHRE)

Extracellular matrix (ECM)

Fibroblast growth factor (FGF2)

Free thyroxine 4 (FT4)

Glycosaminoglycan (GAG)

Granulocyte-macrophage colony stimulating factor (GM-CSF)

Heparan sulfate (HS)

Human Leukocyte Antigens (HLA)

Human Y chromosome (HY)

Interferon-gamma (IFN- $\gamma$ )

Intravenous immunoglobulin (IVIG)

Killer cell immunoglobulin receptors (KIRs)

Leukemia inhibitory factor (LIF)

Lipopolysaccharide (LPS)

Low molecular weight heparin (LMWH)

Lupus anticoagulant (LAC)

Macrophage colony- stimulating factor (M-CSF)

Magnetic-activated cell sorting (MACS)

Mannose-binding lectin (MBL)

Matrix metalloproteinases (MMPs) and their tissue inhibitors (TIMPs)

Mitogen-activated protein kinase (MAPK)

Myeloid-derived suppressor cells (MDSCs)

Natural killer cells (NK)

Normalized Protein eXpression (NPX)

Peripheral blood mononuclear cells (PBMCs) 
Placental growth factor (PIGF)

Pregnancy of unknown locations (PULs)

Preimplantation genetic screening (PGS)

Randomized controlled trial (RCT)

Recurrent miscarriage (RM)

Recurrent pregnancy loss (RPL)

Regulatory T (Treg) cells

Rheumatoid factor (RF)

Royal College of Obstetricians and Gynaecologists (RCOG)

Standard deviation (SD)

Thyroid stimulating hormone (TSH)

Transforming growth factor (TGF)

Tumor necrosis factor (TNF)

Unexplained RPL (uRPL)

Vascular endothelial growth factor (VEGF) 


\section{Thesis summary}

Paper I. Effects of low molecular weight heparin on the polarization and cytokine profile of macrophages and T helper cells in vitro. Sci Rep 2018.

In paper I low molecular weight heparin (LMWH) in vitro effects on activation and polarization of central regulatory immune cells, such as Th cells and macrophages, were assessed, since LMWH has been widely used as an empiric treatment in recurrent pregnancy loss (RPL) and its immunological effects are not fully known. Isolated blood monocytes and Thelper (Th) cells under different activation and polarizing conditions were cultured without or with LMWH at different concentrations. LMWH exposure induced an activated phenotype of macrophages, with high expression of HLA-DR and CD206 assessed by flow cytometry, associated with increased secretion of Th17-associated CCL20, and decreased secretion of CCL2 (M2-associated) and CCL22 (Th2), as measured by multiplex bead array. In accordance, LMWH exposure to Th cells reduced the proportion of CD25highFoxp3+ regulatory T-cells, and intensified IFN-ץ secretion. Collectively, a mainly pro-inflammatory effect was noted on two essential tolerance-promoting cells, suggesting that potential immunological effects of LMWH may be effective mainly at an earlier gestational age to provide an appropriate implantation process in women with recurrent miscarriage.

Paper II. Low-molecular-weight-heparin increases Th1- and Th17-associated chemokine levels during pregnancy in women with unexplained recurrent pregnancy loss: a randomized controlled trial. Sci Rep 2019.

In paper II we investigated whether LMWH could modulate immune responses in vivo during pregnancy of women with unexplained RPL. A Swedish open multi-centre randomized controlled trial included 45 women treated with tinzaparin and 42 untreated women. Longitudinally collected plasma samples were obtained at gestational weeks (gw) 6, 18, 28 and 34 and analyzed by multiplex bead technology for levels of 11 cytokines and chemokines, chosen to represent inflammation and T-helper subset-associated immunity. LMWH-treated and untreated women showed differences during pregnancy of the Th1associated chemokines CXCL10 ( $\mathrm{p}=0.01)$, CXCL11 $(\mathrm{p}<0.001)$ and the Th17-associated chemokine CCL20 ( $\mathrm{p}=0.04$ ), while CCL2, CCL17, CCL22, CXCL1, CXCL8, CXCL12, CXCL13 and IL-6 did not differ. Significantly higher plasma levels of CXCL10 and CXCL11 in treated women were detected at gw 28 and 34, compared to the untreated ones. Thus, a potential proinflammatory effect, linked mainly to Th1 immunity, was shown, suggesting 
an unfavorable effect of LMWH treatment, since Th1 responsea are responsible for breaking the fetal-maternal immune tolerance.

Paper III. First-trimester trophoblasts obtained by chorionic villus sampling maintain tolerogenic and proteomic features in successful pregnancies despite a history of unexplained recurrent pregnancy loss. Am J Reprod Immunol. 2020.

In paper III we investigate the "local" immune changes in women with RPL, since they potentially could reveal important mechanisms in RPL. Supernatants from superfluous chorionic villus sampling material culture was used in an ex vivo model, to determinate the immune proteomics profile and to perform functional assays for M2 like macrophages and regulatory $\mathrm{T}$ cells polarization, assessed by flow cytometry technique. Chorionic villi, human fetally derived placental tissue, were shown to induce an M2 like-phenotype and an expansion of Treg cells in an ex vivo model, and these immunological properties were maintained despite a history of RPL. Accordingly, no differences in the inflammation proteomic profile were found in RPL, compared to controls. Trophoblasts in an ex vivo model thus maintain tolerogenic and proteomic profile features in successful pregnancies, despite a history of RPL. 


\section{Summary in Swedish}

Missfall är en mycket vanlig komplikation under tidig graviditet. När ett par drabbas flera gånger ställs diagnosen upprepade missfall. Definitionen av upprepade missfall är två eller tre på varandra följande missfall, enligt olika internationella "guidelines". I denna avhandling har vi använt definitionen tre på varandra följande missfall, vilket anses förekomma hos 1-3\% av fertila kvinnor. Efter en noggrann utredning kan olika orsaker ofta påvisas, men hos cirka hälften förblir missfallen oförklarade (engelska "unexplained repeated pregnancly loss, uRPL). I dessa oförklarade fall anses immunologiska orsaker med ökad inflammation kunna ligga bakom, även om det inte finns entydiga bevis för detta, och inte heller någon accepterad utredning för att fastställa detta. Tyvärr finns heller ingen behandling med bevisad effekt. En blodförtunnande medicinering, låg-molekylärt heparin (LMWH), har använts en del, trots att klinisk effekt inte bevisats. I vissa fall kan störningar i blodkoagulation orsaka upprepade missfall, men medicinen har även använts vid oklara fall på grund av förmodade effekter på immunsystemet.

I detta avhandlingsarbete har vi studerat immunologiska effekter av LMWH. I det första delarbetet studerade vi effekterna i ett modellsystem in vitro (i provrör). Blodprover från friska försökspersoner användes för att rena fram olika immunceller som sedan exponerades för LMWH i koncentrationer som efterliknar koncentrationerna i blod. Effekterna studerades genom att kartlägga hur cellerna från försökspersonerna ändrades och genom att mäta vilka immunologiska signalmolekyler (cytokiner) som utsöndrades. Den sammantagna bilden var att närvaro av LMWH förändrade cellernas egenskaper till ökad inflammation. Detta fynd var alltså inte i den förväntade riktningen att LMWH skulle minska inflammation, vilket skulle vara gynnsamt vid behandling av upprepade missfall som är associerat med ökad inflammation.

I det andra delarbetet undersöktes immunologiska effekter av LMWH i en kontrollerad randomiserad studie där kvinnor med tre på varandra upprepade missfall lottades till LMWH-behandlingen eller ingen behandling. Båda grupperna hade en hög andel lyckosamma graviditeter, dock var studien inte designad för att besvara frågeställningen om graviditetsutfall. Påverkan på immunsystemets studerades genom mätning av immunologiska signalmolekyler (cytokiner) före behandling och under graviditet. De flesta cytokinerna påverkades inte av behandling, men de som ändrades av behandling visade tecken på ökad inflammation, alltså i linje med resultaten i första studien. Sammantaget ger studierna inga belägg för att använda LMWH baserat på dess eventuella effekter på immunsystemet. En intressant spekulation skulle vara att behandla med LMWH innan graviditet och under den allra första delen av graviditet eftersom en ökad inflammation anses behövas vid själva implantationen. Det behövs dock fler studier innan en sådan möjlighet kan bli aktuell. 
I det tredje delarbetet undersöktes om kvinnor med upprepade missfall har normal immunfunktion vid lyckosam graviditet. Det visade sig att så var fallet, vilket delvis kan förklaras av att proverna togs så sent som i graviditetsvecka 12, och de flesta missfallen inträffar tidigare. Resultaten tyder också på att upprepade missfall inte måste innebära bestående avvikelser i immunsystemet, det vill säga trots en historik med minst tre missfall hade den undersökta gruppen en normal graviditet och immunfunktionen var normal. 


\section{Preface}

Recurrent pregnancy loss (RPL) is a debated condition both from a research and from a clinical point of view. Diagnostic work-up, management and treatment, have not reached a common shared agreement, despite the recommendations included in the most recent guidelines (ESHRE 2017). This is especially pertinent in relation to unexplained RPL (uRPL), where an etiological factor cannot be found and no treatment is recommended, even if a wide empirical use of for example low molecular weight heparin (LMWH) has been done mainly based on its anticipated immunological properties. The lack of an evidence-based level in this field, due to the difficulties to perform systematic reviews or metanalysis, is influenced by differences in definition, etiological factors, management, and therapeutic strategies considered-

The aim of this thesis is to further assess the potential immune tolerance disruption at the fetal-maternal interface associated with URPL and to decipher the immunological effects of $\mathrm{LMWH}$ in vitro and in vivo.

\section{RPL Background}

\section{Evolution in definition of RPL and its clinical implications in prognosis}

According to the most recent guidelines (ESHRE 2017, European Society of Human Reproduction and Embryology) (1), RPL is defined as the loss of two or more pregnancies before the 24th week of gestation. According to the previous ESHRE guidelines and the 2011 RCOG (Royal College of Obstetricians and Gynaecologists) Green Top Guideline, recurrent miscarriage (RM) was defined as three or more consecutive pregnancy losses before 20 and 24 weeks of gestation, respectively(2-3). Conversely, ASRM (American Society for Reproductive Medicine) guidelines already in 2013 (4-5) defined RM as two or more failed clinical pregnancies, not necessarily consecutive, before 20th week of gestation. The scientific trend of RPL definition implies that clinical evaluation on RPL couples should be done after the second pregnancy loss, which has huge implications for individuals and society. Regarding common etiological factors, one study has shown that proven or probable causes of RPL occur with equal frequency in women with two pregnancy losses versus three or more(6).

In the ASRM definition, miscarriages should be related to failed clinical pregnancies, therefore an ultrasonography or histopathological examination is needed to support the diagnosis. Conversely, the ESHRE guidelines take into account non-visualized pregnancy losses (a wide spectrum of clinical conditions ranging from biochemical pregnancy losses to failed 
pregnancy of unknown locations, PULs), since they too have a negative prognostic value on subsequent live birth chances in early uRPL (occurring before 10 week of gestational age)(7). Therefore, RPL is the more appropriate term to use according to the 2017 ESHRE guidelines, since RM includes only intrauterine clinical miscarriages(1).

Primary RPL occurs if there is no previous pregnancy (viable pregnancy) beyond 24 weeks of gestation. Conversely, RPL that occurs after one or more previous pregnancies progressing beyond 24 weeks of gestation, is defined as secondary. These definitions are common for the different guidelines, while the question of consecutive pregnancy losses has changed. Both the ESHRE guidelines 2017 and the ASRM 2013 Practice Committee claim that pregnancy losses could be non-consecutive, which is in contrast to previous definitions $(8,5,9)$. Regarding secondary RPL prognosis, a live birth could reduce previous pregnancy losses negative influence, since a previous successful pregnancy may confer an immunological memory in suppressive regulatory $\mathrm{T}$ cells in peri-uterine lymph nodes, and therefore the immune response against fetal antigens $(10,11)$. This immunological feature is lacking in primary RPL patients, since they show an aberrant endometrial periimplantation memory $\mathrm{T}$ cell phenotype (12). These observations suggest the possibility of stratifying RM patients, since they comprehend a broad heterogeneous population (13). A better stratification could also lead to individualized treatment.

The different immunological background in secondary RPL patients could impact the prognosis $(10,11)$. Secondary, rather than primary RPL, show not only enhanced memory Treg cells function, but also higher TNF levels in early pregnancy, in which a genetic background could have a role (14). Furthermore, in secondary RPL a higher rate of aneuploidy has been detected. These patients could, therefore, take advantages from a preimplantation genetic screening (PGS) (15). Secondary RPL is also associated with a specific immune response towards male-specific minor antigens, associated with specific HLA alleles (HY(human Y chromosome)-restricting HLA class II alleles)(15-18).

RPL is associated with an increased risk for obstetrical complications and adverse pregnancy outcomes, such as preterm delivery, fetal growth restriction, and gestational diabetes mellitus, with a major incidence in primary RPL (19). RPL patients should undergo a more strict follow-up for early detection of obstetrical complications (19).

No differences between primary and secondary RPL have been found in the proportion of etiological factors (Chromosomal abnormalities; Uterine anatomic defects, such as septum, unicornuate and bicornuate uteri, fibroids and polyps $>1.0 \mathrm{~cm}$ in the uterine cavity, and Asherman's syndrome adhesions; Autoimmune disorders, Lupus anticoagulant (LAC); 
Anticardiolipin antibodies (ACA); Factor V Leiden mutation; Mutations for the G20210A prothrombin (factor II) gene; protein C, protein S, antithrombin III; Thyroid function (Thyroid Stimulating Hormone), Antithyroid peroxidase (anti-TPO) and antithyroid antibody; Blood glucose level; Antinuclear antibody (ANA); Rheumatoid factor(RF)) (19).

In our work we used the more stringent definition of RPL, defined as three or more consecutive miscarriages before 22 gestational weeks.

\section{Risk factors}

Obesity and age are considered known risk factors for RPL. Another factor that has been associated with RPL, because of psycho-neuro-endocrine-immunological connections, is stress. Nevertheless, there is no evidence to support stress as a direct cause for pregnancy losses. Screening for endometritis or abnormal decidualization, which seem to be implied in RPL, are not recommended, since an evidence-based level has not been reached (1).

\section{Etiology}

Despite several known etiological factors for RPL have been detected, such as uterine abnormalities, hormonal causes, parental chromosomal abnormalities, autoimmune diseases, antiphospholipid antibody syndrome and major thrombophilia, approximately $40-50 \%$ of the cases are estimated as unexplained (1). The frequency of uRPL is estimated to $1-2 \%$ of fertile women $(1)$.

RPL is commonly associated with the presence of several slight aberrations, depicting a threshold model similar to multifactorial diseases approach: a major etiological factor that can directly explain the pregnancy losses cannot be found in the majority of the cases. Therefore, a threshold model instead of a pie one better describes RPL etiology (20).

\section{Unexplained RPL}

An aberrant immune response at the fetal-maternal interface has been hypothesized to be involved in URPL. Inflammation and immune tolerance are tuned throughout pregnancy; an inflammation process is required for a proper implantation process in the earliest stages. Then, a switch to immune tolerance takes place in order to promote a "non-rejection" of the semi-allogenic fetus. The "gatekeepers" of this key immune switching at the fetal maternal interface are the decidualized stromal cells (21-24). In addition, the trophoblast cells have 
an important role in promoting tolerance (25). The tolerance promoting environment also involves several subtypes of immune cells such as regulatory T cells, NK cells, and immune regulatory macrophages, all interacting with each other and with tissue cells (26).

Labor onset requires an inflammation process, which implies a new immune switching (2632). Pregnancy complications, such as RPL, are potentially associated with alterations in placentation and immune system tuning (33-35). uRPL can be considered, indeed, as an immune pathological condition in which an increased pro-inflammatory response (enhanced Th1, Th17 responses; reduced Th2 responses and lower levels in Treg and uNK cells), predisposition to break autotolerance (autoantibodies involved: ACA, ANA, anti dsDNA, anti-TPO) and dysregulation of the maternal immune response to fetal or trophoblast antigens (molecules involved: killer cell immunoglobulin receptors (KIR), HLA, mannosebinding lectin (MBL), HY) occur (36).

Maternal-fetal interface immune tolerance establishment requires epigenetic modifications in fetally derived trophoblastic tissue, but also at the maternal side, the decidua. Indeed, the relative exclusion of $\mathrm{T}$ cells in the decidua has been shown, in mice, to be caused by epigenetic silencing mechanisms in decidualized stromal cells of genes encoding $\mathrm{T}$ cell recruiting and inflammatory chemokines (37). Epigenetic gene silencing mechanisms could reveal potential targeted therapeutic approaches in pregnancy complications, such as uRPL(37).

\section{General prognosis}

Two thirds of RPL women had at least one live birth after a first consultation at an RPL clinic, with a child born within 5 years (38). Increasing number of previous miscarriages and age at first consultation negatively affect the chance of subsequent live birth rate (38). Furthermore, it has been shown that secondary RPL pregnancies have a better prognosis compared to primary ones, since, as mentioned before, a live birth could reduce negative immunological influence from previous pregnancy losses $(10,11)$. Consistently, there is an immunological memory acquired for each pregnancy (39-40) and if no etiological causes can be identified for RPL, the general prognosis of subsequent pregnancies for unexplained RPL is good (41). Indeed, it has been suggested that unexplained/idiopathic RPL could be considered as a chance occurrence given the high general frequency of pregnancy losses (42). Saravelos et al (43) propose to stratify idiopathic RPL patients in two subgroups, women with RPL that probably has occurred predominantly by chance, without any specific underlying pathology, and women with uRPL that occur due to an underlying pathology. 
While the first group has a good prognosis for subsequent pregnancy live birth, conversely the second one has a poorer prognosis (43).

\section{Potential therapeutic approaches in uRPL}

Several treatment strategies have been considered to be potentially effective, such as intravenous immunoglobulin (IVIG), progesterone, acetylsalicylic acid (ASA), leukocyte immunization treatment, low molecular weight heparin (LMWH) and corticosteroids. Nevertheless, no evidenced based approaches have been achieved in order to confirm their efficacy (1), which is reflected in the recent ESHRE guide lines. However, LMWH has been widely used and still is used in clinical practice as an empirical therapy. Beyond its wellknown anticoagulant effects, LMWH potentially exerts immunomodulatory and antiinflammatory effects, which could counteract the dysregulated pro-inflammatory environment in RPL. Furthermore, LMWH could play a role at the fetal-maternal interface in the prevention of trophoblast apoptosis, the increase in trophoblast invasion, the improvement of endothelial and vascular microenvironments, the regulation of embryo implantation, and the modulation of endometrial stromal cells (ESCs) decidualization by improving endometrial receptivity and supporting early implantation (45). These processes may be aberrant in women with RPL (45). In addition, it has been suggested that women with RPL have an endometrial super-receptivity (46-47). Thus, an implantation window extension may occur, and, in turn, the decidualized endometrium could allow the implantation also of a poor-quality embryo (46).

LMWH is not recommended in URPL, since studies have failed to show evidence for increase in "live birth rate" (1). Several studies show discrepant results, which is in part caused by differences in the study design (in terms of definition, randomization and starting-week of treatment, diagnostic screening applied for uRPL). Accordingly, in the most recent ESHRE guidelines, LMWH is not recommended in uRPL. (1).

\section{Heparin structure and its interactions}

Heparin is made of highly sulphated linear glycosaminoglycan made of repeated sulfated disaccharides and it has a structure similar to heparan sulfate (HS), the glycosaminoglycan (GAG) part of many cell surface and extracellular matrix (ECM) proteoglycans (48).

Furthermore, heparin can bind and regulate multiple functional proteins such as coagulation cofactors, chemokines, and growth factors, by playing a role, in cell attachment, 
migration, invasion and differentiation, morphogenesis, organogenesis, blood coagulation, lipid metabolism, inflammation, and responses to injury, similar to HS. This heparin vast field of actions ha recently led to the concept of a heparin interactome: proteins with their related interactions net-work are therefore known as heparin/HS interactome (48).

Concerning immunological effects, heparin interactions network is also linked to chemokine gradients formation, which guides immune cells migration, since GAGs are involved in inducing and stabilizing chemokines oligomerized states. Chemokines and cytokines involved in heparin interactome are mostly IL-8/CXCL8, followed by CXCL12, CXCL1, CXCL11, interferon-gamma (IFN-ү), IL-10 and CCL2 (48).

LMWH, which is produced by physical separation, or by controlled chemical/enzymatic cleavage of heparin (depolymerization), is widely used nowadays, since it maintains anticoagulant activity while having fewer side effects, such as hemorrhage and reduction of hematoblasts, compared to heparin. Furthermore, it has better pharmacokinetics, longer half-life, better bioavailability, higher safety and reduced polydispersity (49).

\section{Known immunological effects of Low Molecular Weight Heparin}

Despite the above considerations, the mechanisms through which LMWH can modulate the immune response are not clearly understood, especially those involving the adaptive immune system. LMWH exerts its influence on the innate immunity by inhibiting leukocyte rolling, cellular adhesion and transmigration through the endothelium (50). Moreover, LMWH can also bind to the monocytes cell surface (51-52) and enhance monocytes LPSinduced pro-inflammatory cytokine secretion, such as CXCL8 and IL-1 $\beta$ (53-54). Conversely, other studies show that LMWH can reduce monocytes' secretion of proinflammatory cytokines such as IL-1 $\beta$, IL-6 and TNF (55-57). Thus, the role of LMWH on the immune response is not established, since both pro-inflammatory and antiinflammatory properties have been showed. Furthermore, there is no data available about a potential role of LMWH in macrophages polarization process, which is a crucial point in immune modulation at the maternal-fetal interface. For a successful pregnancy, macrophages polarized to M2 macrophages, as well as regulatory T (Treg) cells, are major players in promoting immune tolerance (25), mechanisms that are suggested to be inadequate in RM (36).

LMWH effects on T cells have not been deeply investigated. One study suggests an increase in Treg cells in peripheral blood in vivo induced by LMWH treatment (58). It would be important to further analyze the potential immunological properties of LMWH, with a particular regard to the effects on macrophages and $\mathrm{T}$ cells, two key players in the immune 
tolerance during pregnancy, and potentially also involved in pregnancy complications, such as URPL.

\section{Immune tolerance establishment in physiological and uRPL pregnancies}

The immune system plays a major role in each pregnancy step: initiation, propagation and termination of pregnancy (26). The interplay between inflammation and immune modulation is finely tuned throughout pregnancy to ensure a successful outcome, avoiding obstetrical complications, such as recurrent pregnancy loss, preeclampsia, gestational hypertension and preterm birth (59). At a very early phase in pregnancy an inflammatory process is required to promote a proper trophoblast invasion and implantation process. In particular, in the early implantation phase and during the window of implantation, decidualized stromal cells are considered as the "gatekeepers" of immune cells. The decidual stromal cells (DSCs) interact with and instruct several immune cell types, such as regulatory macrophages, NK cells and T cells. Decidualized stromal cells can induce a proinflammatory response, which leads to the expression of genes implicated in endometrial receptivity, which is followed by an anti-inflammatory response essential for postimplantation embryo survival and development, and for a balanced trophoblast invasion (47). The decidualization process (which is abnormal in vitro in women affected by RPL) (46) is crucial for pregnancy outcome, since it controls not only trophoblast invasion, but it also confers immune tolerance towards the fetus (21). It has been hypothesized that an inadequate implantation process, with a weak pro-inflammatory response, could be a contributing factor to RPL (38). The early controlled inflammatory process should switch, as mentioned, to a subsequent immune response modulation to avoid the "rejection" of the semi-allogenic fetus. However, the break of this tolerance is necessary at term, therefore a new immune switching is required. Specifically, the induction of an inflammation status is crucial to induce labor (60-63). It should be noted that the length of the inflammatory/tolerance phases are not known, and that inflammation and tolerance occur together in a delicate balance. For example, during implantation, tolerance is induced in parallel with inflammation in order to achieve a "controlled inflammation".

\section{The fetal-maternal interface}

Trophoblasts have a key role in initiating and maintaining tolerance at the fetal-maternal interface. After implantation, the uterine decidualized endometrium is infiltrated by trophoblast cells of fetal origin, and in order to regulate trophoblast invasion, and to promote fetal tolerance and homeostasis, the decidua holds a unique composition of immune cells with specialized properties (25). Accordingly, it has been shown in an in vitro model that placental explants were able to induce M2 macrophages and Treg cells, i.e. main 
key immune modulatory cells (25) for fetal tolerance establishment (27-28). Trophoblasts from normal pregnancies displayed these immune modulatory properties, while it is not known if these properties are disrupted in pathological conditions. Accordingly, aberrant activation and polarization of both cell types within the context of a dysregulation in trophoblast immunological functions may be involved in pregnancy complications including RPL.

Indeed, it has been shown that trophoblast dysfunction, due to compromised trophoblast infiltration and apoptosis, as well as multiple aberrant signal transduction pathways (64), could lead to adverse pregnancy outcomes, including uRPL (65). In detail, all the impaired pathways previously investigated in RPL trophoblast cells functions (including kisspeptin/GPR54 and PIBF/PR pathways, C4d and Bb, MBL, NOD1 and NOD2 via MAPK/p38 pathway, miR-27a-3p/USP25 axis, Fas and FasL, PKC protein, CCNA2, TWIST, Prototype and Chimera-Type Galectins, miR-520 and PARP1, BMAL1 via SP1DNMT1/DAB2IP pathway, EIF5A1 via ARAF-mediated activation of integrin/ERK signaling pathway, Stathmin-1, peroxiredoxin2are) are linked to trophoblast migration, proliferation, invasion and apoptosis processes potentially relevant for RPL pathogenesis $(64,66-78)$. Less is known about potential immunological impaired processes induced by trophoblast dysfunction.

To sum up, decidual macrophages and Treg cells are of particular relevance in fetalmaternal immune tolerance; both cell types being enriched in the decidua and with an immune regulatory profile (27-28). The decidual macrophages are of a regulatory M2-like phenotype (29-30) and Treg cells (31-32) show an augmented suppressive profile in the decidua. Accordingly, aberrant activation and polarization of both cell types may be involved in pregnancy complications including RPL, as has been shown for macrophages (79) and by an altered Treg/Th17 balance (33).

\section{Interplay between immune and angiogenesis stimuli during pregnancy}

The activation of a proper placental angiogenesis process, leading to the creation of an efficient vascular network, is promoted by the inflammation status at early pregnancy (8081). The decidual immune cells are responsible for the production and release of angiogenic factor (82-83), such as vascular endothelial growth factor (VEGF) (84), placental growth factor (PlGF), fibroblast growth factor (FGF2) (85) matrix metalloproteinases (MMPs) and their tissue inhibitors (TIMPs)(86), which placenta is enriched of during pregnancy. The placentation process is therefore supported by an adequate angiogenesis process through the release of cytokines, growth factors and chemokines. Accordingly, neutrophils (87) and dNK (88) represent the major suppliers of angiogenic factors supporting a proper 
placentation (87). Proangiogenic cytokines release, such as VEGF, CXCL8, MMPs is also associated with decidual macrophages (89).

\section{Innate immune response players \\ Natural killer cells (NK)}

Decidual Natural killer cells (dNKs) show a tissue-specific phenotype (CD56 superbright CD16$\left.\mathrm{CD} 49 \mathrm{a}^{+} \mathrm{CD}^{+}\right)$compared to the peripheral counterpart, and they represent approximately $50-70 \%$ of the immune cells in the decidua in the first trimester (90). dNKs have more immunomodulatory than cytotoxic behavior, by inducing a tolerogenic environment to host the fetus (91-92). Furthermore, dNK cells are crucial for spiral artery remodeling and trophoblast invasion, by producing angiogenic cytokines and growth factors $(88,90,93-94)$. A dysregulation in cytotoxic and regulatory NK cells function may be involved in pathogenesis of uRPL (90).

\section{Dendritic cells}

Antigen-presenting dendritic cells (DCs) play a key role in the framework of decidual T cell polarization by secreting immunosuppressive cytokines. An absence of uterine DCs impairs the decidualization process in mice, potentially leading to embryo resorption (94). DCs are also involved in angiogenesis, and impairement of this process is suggested to result in aberrant blood vessels maturation and impaired endothelial cell survival, involving VEGFR1 and TGF (transforming growth factor)- $\beta 1$ pathways (94).

\section{Macrophages}

Macrophages can be classified into M1 and M2 subtypes based on their phenotypical and functional properties. Monocytes polarization occurs according to microenvironment stimuli hold in tissues into which the monocytes migrate. M1 macrophages are responsible for a mainly pro-inflammatory Th1-associated response, while M2 macrophages were initially thought to have a role mainly in Th2-associated responses (95). However, it subsequently became clear that several variants of M2 macrophages exist, and that decidual macrophages are similar to M2 macrophages induced by IL-10 and M-CSF $(25,30)$. During the implantation process, decidual macrophages are thought to polarize into an M1 phenotype, followed by switching to a transition stage of mixed M1 and M2 macrophages during extravillous trophoblast invasion (96). Thereafter the M2 phenotype becomes predominant when the proper uterus-placental blood supply is guaranteed, to establish the proper fetal-maternal tolerance (96). Decidual macrophages are crucial in immune regulation, tissue remodeling, cell proliferation, and metabolism within the early pregnancy fetal-maternal interface (29). Trophoblast-derived macrophage colony- stimulating factor (M-CSF) and IL-10 $(25,96)$ mainly induce polarization to decidual $\mathrm{CD} 14^{+} \mathrm{CD} 163^{+} \mathrm{CD} 209^{+} \mathrm{M} 2$ macrophages which is required for exerting an immunosuppressive function and the 
maintenance of a physiological pregnancy $(97,98)$. Accordingly, M1/M2 imbalance may be involved in pregnancy complications, such as RPL (97).

\section{Myeloid-derived suppressor cells (MDSCs)}

Human MDSCs include CD14-CD15+CD66b+ (granulocyte, G-MDSCs) and CD14+/CD15low/- (monocyte, M-MDSCs). It has been shown that first trimester functionally suppressive peripheral and endometrial MDSCs are reduced in miscarriage patients, when compared with successful pregnancies. Indeed, MDSCs have an immunosuppressive role, by inhibiting $\mathrm{T}$ cells and NK cells functions: decidual MDSCs induce Foxp3+ Treg cells proliferation and differentiation, suppression of $\mathrm{T}$ cell proliferation, Th2 response polarization, inhibition of cytotoxic activity in NK cells, potentially involved in a successful pregnancy outcome (99).

\section{Adaptive immune cells}

\section{Thelper cell subsets}

After the Th1/Th2 paradigm was launched, the idea came that pregnancy constitutes a Th2 phenomenon, for example supported by the abortive effects of Th1 responses (100). Subsequently it became clear that this was only in part true, and that Th cell immune regulation in pregnancy was more complex and also may differ locally and systemically (28). Th1/Th2 and Th17/Treg balances are finely tuned during all pregnancy steps. A proinflammatory Th1 framework is required to allow a successful implantation process at the earliest stages of pregnancy, although it is under control of Treg cells. A subsequent shift to Th2/Treg immune response is needed to ensure the proper fetal-maternal interface tolerance (97). CD25highCD127lowFoxp3+ Tregs expansion is induced by placental tissues: Treg expression of suppressive markers, such as CTLA-4 reduces excessive Th cell activation, by decreasing Th1-, Th2-, and Th17-associated cytokines (25).

Although the Th1/Th2 is important for a successful pregnancy and deviant balance can lead to complications (101), also the Th17/Treg cells ratio is crucial. Enhanced Th17 or reduced Treg cells responses have been associated to several pregnancy complications, including RPL (94). Nevertheless, Th17 and Treg cells show a wide extent of plasticity in different "inflammatory frameworks", so that they can switch one another (102).

\section{B cells}

An expansion of CD19+CD24hiCD27+ Breg cells has been suggested to contribute to the immune regulation in pregnancy. Briefly, Breg cell subtypes produce IL-10, which is a key modulator of immune responses during pregnancy, involved in both M2 polarization (30) and expansion of Treg cells (25). IL-10 is also able to maintain DCs in an immature state during pregnancy and to inhibit $\mathrm{T}$ cells activation and Th1 differentiation. Lower 
CD19+CD24hiCD27+ Breg levels in the first trimester has been detected in women affected by RPL (98).

\section{Cytokines and chemokines}

The maternal immune system modulation during pregnancy is orchestrated by cytokines and chemokines (103). Chemokines recruit specific subsets of T-helper (Th) cells, which can be involved in Th1-, Th2- and Th17-associated immune responses (104-109). For instance, the Th1 signature cytokine IFN- $\gamma$ induces CXCL10 and CXCL11 chemokines that bind the CXCR3 receptor on Th1 cells, which are therefore attracted to a Th1 site (106-107,109-110111). CCL17 and CCL22 chemokines, induced by IL-4 and IL-13, are able to recruit Th2 cells, which preferentially express the CCR4 receptor $(106-107,109,112)$. CCL20, induced by IL-17, recruits Th17 cells, which express CCR6 (113,106-109). CXCL12 can recruit T cells and monocytes, promoting a Th2-associated immune response during pregnancy (114). CXCL13 attracts B-cells (106), while CXCL8 recruits neutrophils (115). CCL2 recruits monocytes, is produced by M2-like decidual macrophages and is involved in tolerance at the fetalmaternal interface, by reducing macrophage proinflammatory cytokines release $(30,115)$.

Th1 cytokines have negative effects on pregnancy outcomes. IFN- $\gamma$, by activating cytotoxic T cells and NK cells, can lead to trophoblast injury, to inhibition of granulocytemacrophage colony stimulating factor (GM-CSF) production and inhibition of Th2 cells proliferation. (101).

Furthermore, it has been shown that decidual stromal cells in mice undergo an epigenetic silencing of the genes that encode the Th1-associated chemokines CXCL9, CXCL10 and CXCL11. This inhibition of Th1 chemokine production in the decidua involves changes in histone methylation patterns. Thus, epigenetic mechanisms seem to be involved in fetalmaternal interface immune-tolerance establishment, by modulating $\mathrm{T}$ cells recruitment in the decidual tissue $(10,116)$.

Conversely, a Th-1 associated pro-inflammatory setting is important in the early implantation phase (and during the window of implantation), when decidual endometrial stromal cells induce a pro-inflammatory setting which leads to the expression of genes implicated in endometrial receptivity. The pro-inflammatory setting is followed by an antiinflammatory response essential for post-implantation embryo survival and development, and for a balanced trophoblast invasion (47).

The effects of chemokines are not restricted to recruitment of immune cells. In humans, it has been shown that endometrial epithelial cells and decidual stromal cells express CXCL9-11, while their receptor CXCR3 is expressed also on trophoblast cells and NK cells. The hypothesis is that these chemokines can recruit NK cells to and within the uterus (117). In animal models, CXCL9, CXCL10, and CXCL11 expression seems to be time and site 
specific in the endometrium, with an enhanced pattern at the implantation time. Trophoblast cells, in animal models, express CXCR3 which allows CXCL9 and CXCL10 to recruit and attach trophoblast cells to endometrial epithelial cells (118). 


\section{Aims and Hypotheses \\ General aim}

This thesis work aims at increasing our understanding of the immunological background to RPL, with particular regard to cases in which a main etiological factor cannot be found, and in mechanisms of potential treatment in RPL. An increased knowledge in this area can, in a long-term perspective, lead to better diagnostic tools to subgroup women with RPL and to subsequent individualized therapy. At present, there is no treatment with proven efficacy for uRPL. However, LMWH is widely used for its anticipated potential immune modulatory effects, even if its immunological properties have not been clearly defined.

\section{Specific aims}

Paper I: To assess immunological effects of LMWH on in vitro polarization of macrophages and $T$ cells, key mediators of immune tolerance processes at fetal-maternal interface. Paper II: To evaluate in vivo immunological effects of LMWH treatment during pregnancy in women affected by RPL.

Paper III: To establish an ex vivo model using chorionic villous sampling (CVS) tissues to assess placental function during pregnancy, and to investigate whether placental immune modulatory properties are maintained in successful pregnancies, despite a history of uRPL.

\section{Hypotheses}

In paper I the hypothesis was that the in vitro model would be able to unravel potential LMWH properties in exerting anticipated immunomodulatory and anti-inflammatory effects. Thus, the expected finding was an LMWH-induced increase in M2 polarization and expansion of Treg cells. These properties could potentially counteract the dysregulated proinflammatory environment that characterizes RPL.

In paper III the hypothesis was that LMWH would exert immune modulatory and antiinflammatory effects in an in vivo setting during pregnancy.

In paper III, we hypothesized that tissues from chorionic villous sampling (CVS) would show immunomodulatory effects in terms of macrophage polarization and expansion of Treg cells, but that these effects could be altered in women with RPL. 


\section{Study Design and Methods}

\section{Study design}

(I). To assess the potential immunoregulatory properties of LMWH, with a particular regard to the effects on macrophages and Th cells, an in vitro cellular model was used. In this model, blood samples from healthy female donors were used as a source of cells that were cultured in different conditions in vivo. The effects of LMWH were assessed by characterizing the immunological phenotype of different cell types cultured in the presence or absence of LMWH, and by examining cytokine and chemokine secretion from these cells. In addition, the effects of LMWH on cytokine and chemokine secretion by 1st trimester placental tissue was evaluated, since this pathway could be an indirect way of modulating macrophages and Th cells.

(II). To decipher the in vivo immunological effects of LMWH treatment during pregnancy in women with uRPL, longitudinal measurements of plasma levels of cytokines and chemokines were performed in LMWH-treated and untreated women participating in a randomized controlled trial.

(III). Regarding the investigation of local immune changes, CVS was used as a source of placental tissue from ongoing pregnancy. Small pieces of CVS tissues were cultured ex vivo, followed by collection of the cell-free supernatants. The supernatant is referred to as conditioned medium (CM), since it is conditioned by secreted factors from the cells, in this case mostly the trophoblasts which make up the chorionic villi. The CM is subsequently used in the same in vitro model as in paper I, to; (1) evaluate if CVS can be used as an ex vivo model of placental/trophoblast functional aspects; (2) assess whether or not the immune modulatory properties of trophoblasts are maintained in successful pregnancies, despite a history of uRPL; and (3) characterize the secreted proteomic profile of placental tissues obtained by CVS.

\section{Subjects, ethical permissions and settings}

To investigate in vitro effects of LMWH on macrophages and T cells, blood samples were collected at Linköping University Hospital from 20 healthy non-pregnant female volunteers, between 18-45 years of age, not taking hormonal contraceptives or any other medication. For the in vitro assay with placental tissue, first-trimester placental tissues were collected from 10 healthy pregnant women undergoing elective surgical abortions at Linköping University Hospital (Linköping, Sweden). All pregnancies were viable, and the median gestational week was 10 (range 9-12), as determined by crown-rump length using ultrasound. Misoprostol (Cytotec; Searle) was given to all women prior to surgery. The study was approved by the regional ethical board in Linköping, and written informed consent was obtained from all subjects. All experiments were performed in accordance with the Helsinki Declaration ethical principles for medical research. 
To assess the in vivo immunological effect of LMWH in uRPL, pregnant women without a known cause of RPL, were recruited to an open multi-centre randomized controlled trial (RCT),-conducted from 1 January 2012 to 31 December 2015, in six Swedish centers: Helsingborg, Lund, Kalmar, Jönköping, Karlskrona and Linköping. Viable pregnancies were confirmed by ultrasound. All patients previously undergone a standardized diagnostic workup according to national recommendations, including: a) collection of familial and personal medical, gynecological and obstetrical history with specific references to previous miscarriages; b) gynecological examination; c) transvaginal ultrasound; d) hysterosonography; e) endocrine evaluation panel: thyroid stimulating hormone (TSH), free thyroxine (FT4); e) karyotype of both partners; f) immunity panel: anti-phospholipid antibodies, lupus anticoagulant, anti-cardiolipin antibodies, Anti-Beta 2 Glycoprotein I (anti-ß2GPI), anti-thyroid antibodies (anti-thyroid peroxidase and thyroid receptor antibodies); g) thrombophilia screening: protein C, protein S, homocysteine and determination of the following mutations: factor $\mathrm{V}$ Leiden, factor II prothrombin.

This workup was aimed to identify proven causes of RPL. When all the above known causes for RPL had been excluded, women were diagnosed with URPL and were included in this study. Written informed consent was obtained from all participants.

From the 129 women who were assessed for eligibility, 87 were included for randomization: 45 women to treatment and 42 women to a control group. Eight women miscarried and 73 continued beyond 22 gestational weeks. The regional ethical board in Linköping, Sweden, approved the study. All experiments were performed in accordance with the Helsinki Declaration ethical principles for medical research.

Regarding the CVS ex vivo model, 36 pregnant women at 12 weeks of gestation were included at the Prenatal Diagnosis Unit of Tor Vergata University Hospital between 2014 and 2017. Gestational age was calculated on the basis of the last menstrual period and was confirmed by ultrasonography. Women were divided into two groups: 27 healthy women with singleton normal pregnancy and without obstetrics complications in their past obstetrical history, and 9 women with a history of RPL, now presenting with a singleton normal pregnancy.

Main indications for CVS in our cohort were: advanced maternal age, defined as $>35$ years of age $(n=26)$, maternal/paternal increased risk for genetic inheritable diseases $(n=2)$, balanced chromosomal abnormalities $(n=3)$ and genetic disease healthy carriers $(n=3)$, ultrasonographic soft markers suspected for chromosomopathies $(n=2)$. No woman in our study had a previous pregnancy with fetal chromosomal abnormalities.

All fetuses from pregnancies included in the study had a normal chromosomal map and were negative in a genetic disease test carried out based on the family risk history.

The pregnancies were followed prospectively to assess their outcomes. The study was approved by the Institutional Review Board (IRB) of "Tor Vergata" University in Rome, and a written consent was obtained before performing CVS from each eligible patient. 
For the ex vivo assays, blood samples were collected at Linköping University Hospital (Linköping, Sweden) from 9 healthy non-pregnant female volunteers, between 18-45 years of age, not taking hormonal contraceptives or any other medication. A written informed consent was obtained from all subjects. All experiments were performed in accordance with the Helsinki Declaration ethical principles for medical research.

\section{Experimental design}

In vitro functional study

\section{Cell separation and sorting}

Isolated peripheral blood mononuclear cell (PBMCs), trough LymphoPrep gradient, were used for isolation of CD14+ monocytes or CD4+ $\mathrm{T}$ cells by positive selection using immunomagnetic cell sorting, using Magnetic-activated cell sorting (MS MACS) columns. To analyze the effects of LMWH on Th cells and macrophages, LMWH, Innohep ${ }^{\circledR}$ (tinzaparin sodium) was added to Th cell or macrophage cultures at two different doses: 1 IU and $10 \mathrm{IU}$. These doses correspond approximately to those reached in vivo after low dose intra-muscular LMWH injection, commonly used in the clinical practice for RM patients.

Macrophages were generated from CD14+ monocytes, in the presence of recombinant human granulocyte-macrophage colony-stimulating factor (GM-CSF) or macrophage colony-stimulating factor (M-CSF), in the presence or absence of LMWH. To analyze the effects of LMWH on resting, as well as activated, Th cells, isolated CD4+ T cells were either cultured unstimulated or stimulated with anti-CD3 and anti-CD28 Abs. CD4+ T cells were thereafter cultured, in the presence or absence of LMWH.

To measure the influence of LMWH on placental tissue, we measured secreted cytokines and chemokines from placental explants exposed or not exposed to LMWH in vitro. Immediately after collection of 1st trimester tissue, the decidua was removed, and the fetal placental tissue was processed. The placental villi were dissected into small pieces ( 1-2 $\mathrm{mm}$ in diameter) and they were incubated without or with 1 IU or 10 IU of LMWH. The conditioned medium (CM) was collected for cytokines and chemokines production assays, by Luminex analysis. Major details about methods are provided in Paper I.

To analyze the effects of CVS-CM on Th cells and macrophages, CVS-CM was added to Th cell or macrophage cultures at two different concentrations: $12 \%$ and $25 \%$. The same models of macrophage and Th cell activation and polarization as in paper I were used. In macrophage cultivation experiments, cells were exposed to GM-CSF, M-CSF, 12\% CVS-CM and 25\% CVS-CM in the same experiment. To analyze the effects of CVS-CM on Th cells, isolated CD4+ T cells were also cultured in the presence or absence of CVS-CM. Details about methods are provided in Paper III. 


\section{Macrophage polarization model principles}

M-CSF and GM-CSF are the growth factors used in our model, since they are needed to reliably promote the growth and differentiation of monocytes in vitro with two different polarization pathway phenotypes: M2-like and M1-like, respectively. M-CSF was used in the experiments as a positive control for M2 polarization in paper I and III, and only in paper I to assess whether LMWH can change the M2 phenotype.

Conversely, GM-CSF was used to induce an M1-like phenotype (mainly pro-inflammatory), in order to assess whether LMWH in paper I and CVS-CM in paper III can reverse the M1 phenotype and increase expression of M2 phenotype markers.

\section{Flow Cytometry analysis of surface and intracellular markers expression}

Regarding the LMWH in vitro study, cells were stained with Abs for extracellular staining and their corresponding isotype controls (as shown in Table 1). Alternatively, cells were stained with 7-aminoactinomycin D and Annexin V-PE, which were used to assess viability. After extracellular staining, cells were permeabilized to be stained with anti-human Foxp3, T-bet, GATA-3, or ROR- $\gamma t$ (for Ab details, see Table 1). Data were acquired using a FACSCanto II and analyzed with FACSDiva software version 6.1.2 and Kaluza software version 1.1. For details regarding gating strategies, please refer to Paper I.

\begin{tabular}{c|ccc}
\hline Cell type & Antigen & Fluorochrome & Paper \\
\hline Macrophages & HLA-DR & FITC & I and III \\
\cline { 2 - 4 } & CD 163 & PE & I and III \\
\cline { 2 - 4 } & CD 206 & APC & I and III \\
\cline { 2 - 4 } & CD 209 & PerCP-Cy5.5 & I and III \\
\cline { 2 - 4 } & CD86 & V450 & I and III \\
\hline \multirow{4}{*}{ T helper cells } & CD4 & FITC & I and III \\
\cline { 2 - 4 } & CD25 & PC-7 & I and III \\
\cline { 2 - 4 } & GATA-3 & PerCP-Cy5.5 & I \\
\cline { 2 - 4 } & Foxp3 & PE & I and III \\
\cline { 2 - 4 } & Roryt & APC & I \\
\cline { 2 - 4 } & T-bet & Pacific Blue & I \\
\hline
\end{tabular}

Table 1. Antibodies used for flow cytometry.

With regards to the CVS study, cells were stained with Abs for extracellular staining (for Ab details, see Table 1). LIVE/DEAD ${ }^{\mathrm{TM}}$ Fixable Aqua Dead Cell Staining was used to assess cell viability. After extracellular staining, cells were permeabilized by using the Foxp3 staining kit, followed by staining with anti-human Foxp3 (for Ab details, see Table 1). For details regarding gating strategies, please refer to Paper III. 


\section{Luminex analysis for cytokines and chemokines production}

To investigate in vitro LMWH effect, multiplex bead assay kits were used to analyze supernatants from Th cell cultures for the following factors: GM-CSF, IL-2, IL-10, IL-17A, IFN- $\gamma$, IL-1 $\beta$, IL-6, TNF; and supernatants from macrophage cultures for CCL2, CCL22, CCL20, CXCL1, CXCL10, IL-12 p70, IL-23, TNF and IL-10. CM from placental explants were analyzed for CCL2, CCL22, CCL20, CXCL10, CXCL1-3, CXCL8, GM-CSF, M-CSF, IL-10, IL$1 \beta$, IL-6, VEGF, TRAIL and sFasL. The analyses were performed using the Luminex 200 IS system and the MasterPlex QT 2010 software.

To assess the immunological effects of LMWH in vivo, multiplex bead assay kits were used to analyze plasma samples for the following analytes: CCL2, CCL17, CCL20, CCL22, CXCL1, CXCL8, CXCL10, CXCL11, CXCL12, CXCL13, IL-6 (please refer to table 3 in paper II). The analyses were chosen to represent inflammation and immunity associated with subsets of T helper (Th) cells: Th1 (CXL10, CXCL11), Th2 (CCL17, CCL22), Th17 (CCL20, CXCL1, CXCL8), as well as B cells (CXCL13), general inflammation (IL-6, CXCL8), monocyte recruitment and Th2/anti-inflammatory (CCL2) and monocyte/T cell recruitment and Th2 (CXCL12). The measurements were performed using the Luminex 200 IS system and the MasterPlex QT 2010 software. Details about methods are provided in Paper II.

\section{RCT}

Once pregnancy was verified by ultrasound, all 87 eligible participants were recruited and randomised to one of the following groups.

Group 1 (study [LMWH] group) included 45 patients who received tinzaparin sodium (Innohep 4500 IU; LEO Pharma A/S, Denmark) by subcutaneous daily injections until gestational week (gw) 37. Group 2 (control group) included 42 patients who neither received active treatment, nor placebo.

Enrolled patients were randomized through sequentially numbered closed envelopes opened consecutively at each inclusion point. Eligible patients were randomly assigned to one of the two study groups according to the envelope noting the intervention type. Once allocation was obtained, it could not be changed.

Longitudinally collected blood samples were obtained at four different time points during pregnancy: inclusion time point, before starting treatment (median gw 6, range 5-10), gw 18 (median 18, range 16-18), gw 28 (median 28, range 26-30), and gw 34 (median 34, range $32-37$ ), and at 2 weeks' postpartum. If a woman miscarried, the pregnancy stopped before the second sample time-point, and only inclusion samples were obtained. As we performed paired data analyses to evaluate LMWH effects during pregnancy, women with miscarriages were not included in the further analyses. 


\section{CVS technique}

An ultrasound Eidos Hitachi equipped with a transabdominal 3.5-MHz Biopsy Convex Probe was used to guide CVS. All the procedures were done transabdominally by the same expert operator (AP) with the patient placed in a supine position. An $18 \mathrm{G}$ needle was used based on a common clinical protocol approved to obtain a proficient material quality assay. The skin was sterilized with topical application of povidone-iodine. The needle was flushed with $0.5 \mathrm{ml}$ heparin before the procedure. An appropriate site was selected during a preliminary ultrasound examination, and then a needle was introduced under ultrasound guidance until the placenta was reached. Once the needle tip was in place, the stylet was withdrawn and a 10-ml syringe with $5 \mathrm{ml}$ of culture medium was attached to the needle hub. Aspirations of chorionic villi were performed in a manual mode. A tissue sample was obtained by moving the plunger of the syringe upward in order to create the discontinuous negative pressure necessary, while the needle was advancing through the chorion. Then the needle was moved forward and backward to obtain adequate specimens from various sites. Villous sampling was performed in all cases with a single needle insertion and an amount of about $50 \mathrm{mg}$ of sample (range 40-60) was sent for cytogenetic analysis. Superfluous material, which remains after the routinely clinical investigations, has been used as explants to collect the conditioned medium.

Immediately after CVS collection, the decidua was removed, and the fetal placental tissue was processed. CVS specimens were handled according to our previous protocol for placental explants (Paper I). The conditioned medium, after the incubation period, was collected and processed as described before. The CVS technique is briefly illustrated in figure 1 .

\section{Proteomic assays}

The Olink ${ }^{\circ}$ Inflammation panel kit (https://www.olink.com) was used for the proteomics assay of CVS-CM. This panel includes 92 inflammation-related protein biomarkers, involved in several biological processes, as categorized by GO terms; apoptotic processes, cell activation, cell adhesion, cellular response to cytokine stimulus, chemotaxis, extracellular matrix organization, inflammatory response, mitogen-activated protein kinase (MAPK) cascade, regulation of immune response, response to hypoxia and secretion.

Protein levels are linearized on a log2 scale and expressed as Normalized Protein eXpression (NPX) units. Proteins with more than $50 \%$ of values under the detection limit were excluded from the analysis (CCL11, CCL19, CCL25, CD6, CX3CL1, FGF-5, FGF-23, IL2, IL4, IL5, IL7, IL-10RA， IL13，IL-15RA， IL-17A，IL-17C，IL-20，IL-22RA1，NRTN, NT-3, SLAMF1, TRANCE). All samples were sent to and analyzed by the Clinical Biomarker Facility Unit at SciLifeLab in Uppsala, Sweden. Paper III experimental study design is shown in figure 1. 


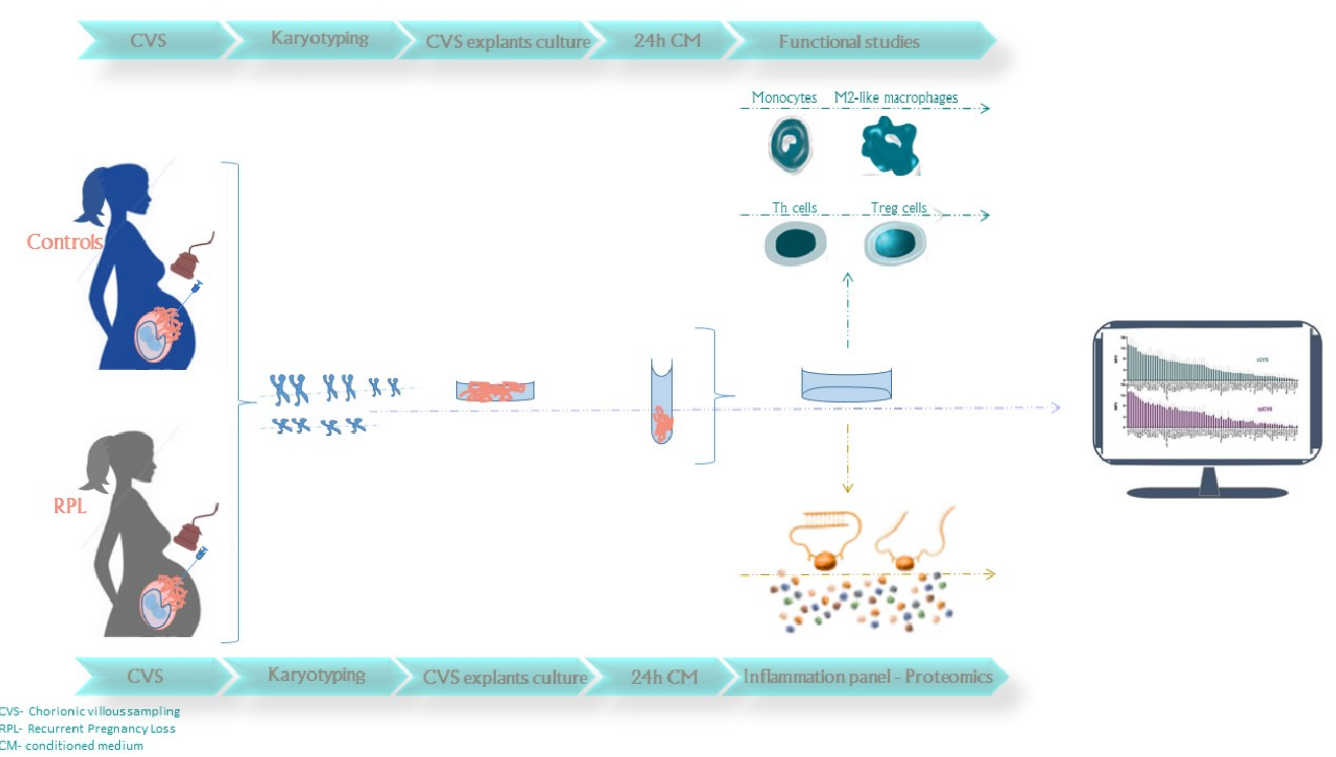

Figure 1. Paper III experimental study design.

\section{Statistical Methods}

Kolmogorov-Smirnov test was used to analyze data distribution.

In paper I, the majority of the flow cytometry data was normally distributed and therefore analyzed with one-way ANOVA followed by the Sidak's post hoc test for paired data. The Pearson's test was used for correlations between parameters. Data from multiplex bead assays were not normally distributed and accordingly analyzed with the Friedman test followed by the Wilcoxon matched-pairs tests. Differences were considered statistically significant when the several-group comparison (ANOVA or Friedman test) was $p<0.05$ and the post hoc test (Sidak or Wilcoxon) was $p<0.05$, while differences were considered a tendency when the several-group test was $p<0.09$ and the post hoc test was $p<0.05$. Flow cytometry data are expressed as mean and standard deviation (SD), whereas data from the multiplex bead assay are presented as medians and inter-quartile ranges. All data were analyzed using GraphPad Prism version 6.0 and version 8.2.0 (La Jolla, CA, USA).

Regarding the RCT in paper II, since the Kolmogorov-Smirnov test showed that data on cytokines and chemokines were not normally distributed, they were normalized by logarithmic transformation. First, Linear Mixed Models were used to evaluate differences between treated and untreated women in any of the cytokines and chemokines during the course of pregnancy (by including samples at inclusion, and weeks 18, 25 and 35). This test was chosen since it, unlike repeated measures ANOVA, allows missing values. If $\mathrm{p}<0.05$, 
a post-hoc test was done to decide at which time point(s), and in which direction, there was a difference. As only three chemokines were $\mathrm{p}<0.05$ in the linear mixed model test, the posthoc testing in these cases was done with ordinary Student's t-test or Fisher's exact tests; the latter was used in one case (CCL20) because of the low proportion of samples with detectable levels. Student's t-test on log-transformed values was used to analyze differences in cytokine/chemokine levels at inclusion and at 2 weeks' postpartum. Data were expressed as geometric mean and $95 \%$ confidence intervals.

In paper III, the majority of the flow cytometry and proteomics data was normally distributed, and therefore one-way ANOVA followed by the Sidak's post hoc test for paired data was used to compare flow cytometry data, and two-tailed Student's test was used to compare protein levels, in women with and without a history of RPL. Pearson's test was used for testing of correlations between parameters. Demographic and clinical characteristics of the different groups were analyzed and compared by Student's test or Fisher's exact test. P values < 0.05 were considered statistically significant. All data were analyzed using SPSS version 24 (Armonk, NY: IMB Corp.). 


\section{Results and Discussion}

\section{Immunological effects of LMWH on macrophages, $T$ cells and placental tissues in}

vitro (paper I)

To evaluate LMWH effects on differentiation of monocytes to macrophages, a previously established in vitro model was used (30). The phenotype of macrophages was evaluated by flow cytometry, and their cytokine secretion profile was established by multiple bead methodology. The main finding was that several phenotypic and cytokine secretion changes induced by LMWH were in the direction of an activated and inflammatory phenotype. The expression of the classical activation marker HLA-DR increased at exposure of LMWH, as did the expression of CD206. CD206 has been considered being an M2 marker, but in humans, CD206 expression is induced not only by M2-associated M-CSF, but also by M1associated GM-CSF (30), thereby reflecting a general activation. Furthermore, LMWH was not able to increase expression of the major decidual macrophage marker CD163.

Regarding the profile of cytokine and chemokine secretion, LMWH exposure induced a reduction in CCL2 levels, which is in line with an LMWH-induced pro-inflammatory profile of macrophages. Indeed, CCL2 is released by decidual macrophages (29-30), and has been associated with recruitment of Th2 cells (119), as well as reduced production of proinflammatory cytokines by macrophages (120). Furthermore, LMWH exposure decreased Th2-associated CCL22 secretion, while it increased Th17-associated CCL20. Th17 effects during pregnancy are not clearly clarified, nevertheless it is known as a mainly proinflammatory response (121), while Th2 supports successful pregnancy (121). Taken together, our results (increase in CCL20, decrease in CCL2 and CCL22, together with the activated phenotype) indicate that LMWH-exposed macrophages induce a mainly activated pro-inflammatory profile in vitro. Thus, there was no evidence to support the original hypothesis of LMWH inducing an anti-inflammatory M2-like phenotype that would resemble that of decidual macrophages. To support our results, LMWH has been shown to have direct effect on monocytes, by binding to their cell surface of (51-52), and heparin has been associated with lipopolysaccharide (LPS)-induced inhibition of cytokine secretion (50, $53,55)$. On the other hand, mostly enhanced secretion of proinflammatory cytokines, such as CXCL8, IL-1 $\beta$, IL-6 and TNF by monocytes have been reported (53-57). These partly discrepant results could be due to differences in study design (length and dose of stimulation, isolated or mix of cells, stimulatory conditions, type of heparin, and read-out), choice of donors (sex, age, treatment), and size of the study.

To evaluate LMWH effects on T cells, isolated CD4+ T cells exposed to LMWH were cultured for three days, either unactivated or activated through the T cell receptor (anti-CD3) and by co-stimulation (CD28), i.e. in a way similar to physiological activation. The main findings lend further support to a mainly pro-inflammatory effect of LMWH by showing a decrease in the Treg cells proportion (in the resting condition), and an increase in secretion of Th1- 
associated IFN- $\gamma$ (in the activated condition), as well as a tendency to an increased lymphoblasts proportion. Despite the central role of $\mathrm{T}$ cells in immune regulation, previous studies have not addressed if LMWH may affect T cells. In vivo, one study has suggested that LMWH treatment may increase Treg cell frequency in peripheral blood (58). Thus, LMWH in vivo may be different from in vitro, since several cellular and molecular interactions could occur in vivo, including potential LMWH effects on cell traffic, which has been shown in the context of innate immunity (50). Accordingly, the increase in Treg frequency in blood may not be paralleled at the fetal-maternal interface (28), where potential immune modulatory treatment should be needed at the maternal-fetal interface to tune immune tolerance processes involving Treg cells and regulatory M2 macrophages (25), which are aberrant in RPL (36).

To evaluate LMWH effects on the placenta, explants from the fetal placenta were exposed to LMWV and the effect on cytokine and chemokine secretion was determined by multiple bead methodology. This evaluation was motivated by our previous observation that the placenta, by secretion of cytokines, can affects macrophages and Th cells, thereby inducing a tolerogenic environment (25), hence LMWH could have indirect effects on these immune cells by affecting the placenta. Although only tendencies were found in our data, there were indeed in line with the data on macrophages; a reduction in CCL22 (Th2), an increase in CCL20 (Th17) and IL-6 (pleiotropic but mainly pro-inflammatory). Furthermore, a reduction (tendency) in TRAIL secretion from the placental explants was observed, supporting a role of LMWH in promoting cell survival at maternal-fetal interface (122). However, TRAIL has been shown to have a beneficial role in fetal immune tolerance (123) by expanding the Treg population, which is resistant to TRAIL-induced cell death, while exonasion of other T cells is inhibited, as shown in mice (124). Also in humans, TRAIL could have a beneficial role. We previously reported that TRAIL was produced by trophoblasts and that it contributed to Treg expansion since blocking of TRAIL in human placental explants led to a reduction in Foxp3+ Treg cells (27). Therefore, the LMWH-associated reduction in TRAIL secretion, as well as the changes in chemokine secretion by placental explants could exert negative effects on fetal-maternal immune tolerance, although the findings were not statistically established.

Collectively, the consistent effects of LMWH shown on macrophages, CD4+ T cells and placental tissue are mainly pro-inflammatory and do not lend support for LMWH treatment of RPL based on its immunological effects. Therefore, the current use of LMWH could be non-optimal. Speculatively, LMWH might have a beneficial role in the earliest phases of pregnancy, especially during implantation, when mainly a proinflammatory process is required. Indeed, a weak pro-inflammatory response has been suggested in RPL (38). An early LMWH treatment could also benefit from other effects, such as prevention of trophoblast apoptosis (122), enhancement of trophoblast invasiveness (125), improvement 
of the endothelial and vascular environments, and regulation of embryo implantation (126). Furthermore, LMWH can regulate endometrial stromal cells (ESCs) decidualization, as shown in an in vitro model, by improving endometrial receptivity and supporting early implantation (45). Interestingly, these processes have been shown to be aberrant in RPL women, with a subsequent extension of the implantation window and an increased ability of the decidualized endometrium to allow implantation of poor-quality embryo (endometrial super-receptivity) (35).

A clinical hypothesis from our results could be to administer LMWH in the luteal phase, to benefit on its effects for a proper implantation, since it has also been demonstrated that LMWH, if administered in this specific early phase, could improve the implantation and live birth rates in women with repeated implantation failure undergoing assisted reproduction techniques (127). The majority of clinical trials have not been designed to test the hypothesis regarding the LMWH administration at an early implantation phase (128), and this could partly explain the contradicting data, since non-homogenous data have been merged, even if, hypothetically, an early start of LMWH treatment could be beneficial, while at later gestational ages might have negative effects.

\section{Immunological effects of LMWH on macrophages and T cells in vivo (paper II)}

The in vivo effects of LMWH were tested by an open RCT on pregnant URPL women. The first blood sample was obtained at inclusion early during pregnancy, before start of treatment. The following samples during pregnancy were obtained at gestational weeks 18 , 25 and 35. The immune status was evaluated by measuring plasma levels of cytokines and chemokines that were chosen to represent different types of immune responses. Overall, there were few differences between the LMWH treated and non-treated women, and no changes were in the direction of an anti-inflammatory or pregnancy promoting change. Our main results showed an increase in Th1-associated chemokines CXCL10 and CXCL11 in the second and third trimesters (at gestational weeks 28 and 34) of LMWH treated uRPL pregnancies compared to the non-treated control group. The biological significance of the finding is supported by the fact that CXCL10 and CXCL11 are sister chemokines, both being induced by IFN- $\gamma$ and strongly linked to Th1 responses. A Th1 LMWH induced-polarization is therefore in line with our previous in vitro findings where LMWH induced an enhanced IFN-y production (paper I). To our knowledge, this is the first study assessing the immunological effects of LMWH in vivo in women with uRPL. A previous study evaluated LMWH in vivo effects, but here treatment was given because of thrombophilia (58). The authors reported an increase in Treg frequency, although only Foxp3 was used as marker, which implies a risk of including false positive activated non-suppressive cells (28). Still, it would have been relevant to evaluate Treg frequency in the present cohort. Unfortunately, 
there is no Treg-specific cytokine or chemokine profile, although CCL18 would have been of interest as being associated with Th2 and Treg cells (129). The present study was open, so that women and healthcare providers were aware regarding treatment or not, which, according to the phsyco-neuro-endocrine-immunological axis could have affected psychological behavior and in turn inflammation response (130). In that sense, also "tender, love and care" effects could exert psychological effects in a beneficial way for pregnancy outcome (131-132). The similar high rates of successful pregnancy outcomes in the treated and non-treated group support the presence of a "tender, love and care" beneficial effect. Since only viable pregnancies confirmed by ultrasound were included in our study, this could also affect the high pregnancy successful rate.

Th1 polarization affects negatively pregnancy outcomes, both in animal and human models $(128,36,133,121,134-135,25,48,136)$. However, a controlled Th1-associated proinflammatory framework is crucial in the early implantation phase (133, 137-138), since it is associated with an endometrial receptivity gene expression profile, and later on to a proper switching to an anti-inflammatory response essential for post-implantation embryo survival and development, and for a balanced trophoblast invasion (47). This setting supports our hypothesis based on the in vitro study that LMWH should rather be used at an earlier time point during pregnancy.

The Th17-associated chemokine CCL20 was increased at gw 18 and 34 in treated compared with non-treated women based on being more often detected in the treated group whereas seldom possible to measure in the non-treated group. Th17-associated responses are known to reflect mainly a proinflammatory profile (139), with previously reported enhanced activity in URPL non-pregnant women in parallel with increased Th1 activity (121), even though its role in pregnancy has been not further elucidated. These results should be matched with the knowledge that Th17 / Treg cells ratio has an impact in pregnancy due to the plasticity to switch to one another $(139,28,102,140)$. Indeed, in relation to our previous in vitro findings, LMWH was able to decrease Treg cells and increase Th17-associated CCL20 production (paper I).

Since significant differences have been not detected in our study in IL-6, CCL2, CCL22, CCL17, CXCL1, CXCL8, CXCL12 and CXCL13, it can be affirmed that LMWH does not have a major impact on several circulating cytokines and chemokine during pregnancy. Furthermore, we found Th1-associated CXCL11 levels to be higher in women who miscarried in the trial compared to women whose pregnancy proceeded beyond gw 22, further emphasizing the negative impact of Th1-associated immune responses. Accordingly, several studies have previously shown an enhanced systemic inflammatory response in women with uRPL, with higher levels of inflammatory cytokines, such as TNF, IFN- $\gamma$ and IL-6, which expose women at risk for miscarrying (134-135, 141-145). A balanced 
proinflammatory profile is therefore crucial a for proper implantation and pregnancy continuation, while an uncontrolled inflammation framework could impact negatively on pregnancy $(36,137-138)$. To conclude, the major effects of LMWH fin vivo were increased levels of the Th1-associated chemokines CXCL10 and CXCL11. These findings lend no support to use LMWH in uRPL based on its immunological effects. Further studies are needed to explore the hypothesis of using LMWH-associated proinflammatory effects to ameliorate the defective implantation process in RPL in the earliest stages of pregnancy.

\section{A chorionic villous sampling model shows that first trimester trophoblasts ex vivo maintain their tolerogenic features despite a history of recurrent pregnancy losses (paper III)}

In this paper we developed a model where conditioned medium from chorionic villi, mainly consisting of syncytio- and cytotrophoblasts, obtained from chorionic villous sampling (CVS) was used to study functional effects and protein profiling features. The same functional methods as in paper I were used. CVS from women with a history of RPL were compared with CVS from controls, all (also RPL women) experiencing a successful pregnancy outcome. We found that conditioned medium from chorionic villi was able to induce an M2 like-phenotype, with increased proportions of cells expressing CD14, CD163, CD209, and decreased proportions of CD86+ cells, as well as an expansion in CD25highFoxp3+ Treg cells. Accordingly, previous findings (25) have demonstrated trophoblast cells functions to induce a tolerant and homeostatic environment at the maternal side (26-28,30,37,102,116,139-140,147-148). Interestingly, immunological properties were preserved in RPL women. Furthermore, the inflammation proteomic profile revealed no differences between the RPL and the control group.

Our findings seem to be unexpected, since a trophoblast dysfunction in RPL has been reported in previous studies. Potential explanations could be:

1) the fetal/placental side is not dysfunctional in RPL.

2) these patients have already gone beyond the 12 weeks of gestation, and therefore they succeeded in carrying on the pregnancy beyond the highest incidence period, since miscarriages in RPL mostly occur earlier, with peaks at 6 and 8 weeks (140-150). Previous studies indeed have shown a dysregulation in trophoblast functions in tissues collected before the 12 th of gestation.

3 ) if no etiological causes can be identified for RPL, the general prognosis of subsequent pregnancies for unexplained RPL is good $(132,1)$, due to an immunological memory acquired for each pregnancy (151-152), which could impact future obstetric outcomes.

The strength in using an ex vivo model is to have the possibility to investigate local immunological properties in an ongoing pregnancy where pregnancy outcome will be known, in contrast to previous studies using materials from terminated pregnancies, in a 
setting of voluntary termination of pregnancies or in missed abortions when it is not known if immunological aberrations occur primary or secondary to the miscarriage. CVS model limitations include methods invasiveness, optimal gestational week for the technique application when the majority of pregnancy losses have already occurred, strict clinical indications and not widely used in clinical practice. Nevertheless, our ex vivo model has gained a deeper knowledge in local immune regulation and revealed the secreted protein profile of trophoblast cells in successful pregnancies.

Our proteomics data demonstrates that trophoblast immunological functions are preserved in the RPL condition. In accordance with our previous study based on elective abortions, several Th2 and Th17-associated cytokines were not detected (25). The pregnancy immune paradigm traditionally associates a successful obstetric outcome to a skew towards Th2 rather than to Th1 immune profile, and to a Treg rather than a Th17 profile, since Th1 and probably Th17 are mainly associated with adverse outcome, due to fetal-maternal immune tolerance dysruption $(28,102,139-140$,$) . However, the traditional concept to define$ pregnancy as a Th2 phenomenon (153) seems not to have a great evidence at least locally, since M2 macrophages and Treg cells polarization are determined by mostly a general and Treg-associated tolerogenic microenvironment, rather than being driven by Th2 cells. In support of this notion, M2 macrophages induced by IL4 and IL13 acquire a phenotype that is sharply different from the decidual phenotype (30). Furthermore, first-trimester decidua shows higher proportion of Treg cells rather than Th2 cells (31), and IL-10 reaches higher levels at the fetal-maternal interface, compared with IL-4 (154) and IL-13 (25). To support this concept, IL-20, which has STAT3-induced proinflammatory, angiogenic and proliferative activities, was undetectable in our samples. Interestingly, these activities are antagonized by IL10, which is one of the major responsible factors to induce a proper tolerant uterine environment (155). Accordingly, IL-10 was detectable in our assays, supporting IL-10- induced function in polarizing homeostatic macrophages and Tregs, as our previous functional studies have demonstrated (25). Besides IL-10, placental-induced macrophages are also polarized by M-CSF, which is primarily produced by trophoblast cells (25) and accordingly was shown to be detectable in our proteomic panel. Furthermore, Treg polarization is driven by synergic actions of IL-10, TGF-beta and TRAIL (123-124), all produced by trophoblast cells (25) and confirmed in our present proteomic panel. Also leukemia inhibitory factor (LIF), involved in Treg cells induction of (156-157), was present in our proteomic signature profile.

CCL2 was among the most secreted chemokines detected in our study and is known to be highly produced by decidual macrophages (30) as well as by trophoblasts (25). CCL2 seems to have relevant functions, since it is involved in M2-associated fetal-maternal tolerance, by reducing proinflammatory cytokines macrophage production $(115,30)$. Nevertheless, CXCL1 (induced by IL-17) and CCL20 (responsible for Th17 cells recruitment) (107-109, 113, 158,), as well as Th1-associated proteins, including IFN- $\gamma$ and CXCL9-11, which are 
involved in NK-cells recruitment (118) and in turn regulate trophoblast invasion (47), were detected in the CVS-CM profile. These findings emphasize that a controlled inflammation takes part in the fetal-maternal regulatory process. Furthermore, information from our proteomic panel provides a library for further functional studies of fetal-maternal immune tolerance in physiological and pathological pregnancies. 


\section{Conclusions}

1. LMWH induces in vitro a mainly pro-inflammatory profile on macrophages and T cells, i.e. two central tolerance-promoting cells at the maternal-fetal interface (paper I).

2. These findings are supported in vivo, where LMWH treatment during pregnancy was associated with increased levels of chemokines CXCL10 and CXCL11 indicating a potential Th1-biased proinflammatory effect of LMWH treatment (paper II).

3. The observed Th1 and pro-inflammatory actions of LMWH in vitro (paper I) and in vivo (paper II), together with previously reported anti-apoptotic and invasion-promoting LMWH effects on trophoblasts, could suggest the possibility of using LMWH at an earlier gestational age in women with RPL, where the anticoagulant effect is not the primary goal of treatment, to favour a proper implantation process, which is defective in RPL condition.

4. Surplus material from chorionic villous sampling can be used in an ex vivo model to assess placental functional effects during pregnancy (paper III)

5. Placental immune modulatory effects on macrophages and T cells, as assessed ex vivo by chorionic villous sampling, maintain tolerogenic and proteomic profile features in successful pregnancies, despite a history of uRPL (paper III). 


\section{Future directions}

RPL is a very debated condition, in which many issues concerning definition, etiological factors to investigate or therapies to apply are still controversial. In this line, biomedical engineering and artificial intelligence (AI) could help the clinicians to reach an objectiveness in RPL access to care. This new approach is the further perspective we would like to investigate, since controversial RPL data strengthen the need to combine the information given from new immunological to already known risk prediction factors to better stratify patients.

AI approach could provide a Support Decision System tool to stratify RPL patients and address them to the proper clinical management and in turn to a personalized treatment, since RPL seems to be a very heterogeneous condition, which needs to be further stratified. Furthermore, although there are several known causes for RPL, 40-50\% of the cases remains still unexplained, and the clinical approach to this subgroup of patients is debated. AI could lead the clinicians to reach a more appropriate identification of the risk for each single patient, with particular regard to this this subgroup of patients, uRPL, where the prognosis cannot actually be predicted by the "classical RPL risk factors".

The objective of classifying patients into risk classes and objective targeting them in therapeutic pathways according to their specific clinical features, can be the first step of utilizing AI. The next step would be to reduce the number of clinical investigations and exams needed for defining a specific subgroup of patients and therefore for the prediction of RPL the risk class. This could be also achieved by verifying through AI application, those clinical features that weight more in correctly discriminating against one risk class from another. Furthermore, by an AI algorithm application, it would be predictable each change in the risk patient class, according to the different therapeutic approaches applied.

In addition to using AI for presently tested clinical and laboratory biomarkers and parameters, it would be of value to use new high-resolution techniques to better understand molecular mechanisms, and to stratify patients into subgroups based on mechanisms. For example, the PEA technology, used in paper III, could be of value for a detailed protein profiling of plasma, which could be relevant for identifying different mechanisms or prognostic factors in women with uRPL. Also, micro-RNA (miRNA) hold promise as circulating biomarkers of pregnancy pathologies (159), which is of particular interest since they, as well as proteins, are contained in micro vesicles that emanate from placenta, and therefore should reflect local aberrations (160).

A very important aspect of RPL is to continue the international work to harmonize guidelines and to standardize design of studies and immunological evaluation (1). Indeed 
it is also important to complete well-designed studies in order to obtain evidence to support or avoid different treatment options. One very interesting aspect is the seemingly high efficacy of "tender, love and care" in RPL, since most RCT show that the placebo-treated (or un-treated) group typically has the same very good outcome as the treated group, as evident in paper II.

Furthermore, as stated previously, both paper I and paper II suggest that LMWH treatment increases inflammation, and speculatively, this property could be of benefit when given before and during the early implantation. Although this is an interesting possibility, it would be a big effort to make a proper study, and before doing that further evidence should be gathered. 


\section{Acknowledgements}

\section{Thanks to...}

...Jan Ernerudh, for always supporting me and always believing in my capabilities and personal qualities from the first year I was at AIR. I really think I have been lucky to have had the possibility to have you as a Main Supervisor for my PhD and not only for the research aspects, but also for life in the prospective to build my future from a professional and personal point of view... so thank you so much for the great support you had for me in all these years. I will never forget the really nice words you had for me for my thirty birthday and the nice surprise by all of you from AIR that day. I know I have been a very "difficult" PhD student, but eventually the "liason" Sweden-Italy has worked fine somehow, although the road was not straight all the time... so thanks also to having sometimes bother me!

...Maria Jenmalm, for your always great contribution to my educational and research pathways and for always pushing me to go further and deeper in my training and professional research skills. I will never forget the really nice Swedish traditional dinner you have organized.

...Leif Matthiesen, for having the possibility to arrive in Sweden and start this road toward my PhD. You have been a real Mentor for me not only from a clinical point of view, but also in life. I will never forget all suggestions you gave me, together with your wife, Merethe, for my life and clinical work, when we having dinner in Cannes all together for my first oral presentation in an International Congress. I will always never forget the Italian dinner based on pasta we cook together! Thanks also for your great enthusiasm you always put in your work and for giving your witness for the really important thing in our clinical trip: to always love our work and always do it with all our enthusiasm!

...Emilio Piccione and Adalgisa Pietropolli, for recognizing in me, since when I was a student at the Med. Faculty, a great potential for research and for having guided and supported me straight on this way, by making also possible my PhD finish line.

...Carlo Ticconi, for having addressed me to the RPL research field and to the LinköpingHelsingborg great research/clinical team, where everything starts from.

...Göran Berg, for your precious clinical support and to make possible my clinical training at the Department of Obs/Gyn at Linköping University Hospital, which was a really great professional experience for me. Thanks also for the travel grant, which have supported my scientific work in Sweden.

...Ole Bjarne Christiansen, for having followed and supported my research and clinical growth from afar, but with great interest and confidence in my abilities. 
...Errico Zupi, for having supported me to always follow the professional research pathway I have reached with my own strengths, even if it was not the easiest way, never doubting my skills.

...Judit Svensson-Arvelund, the greatest young researcher I have ever met in my scientific journey, for having taught me all immunological methods I have learned and how to build step by step a research study work, for pushing me to find out in me the determination, motivation and skills to start a path away from my clinical training. Thanks also for your sincere friendship, for having shared our life experiences and for having always make me feel I was at home.

...Robert Lindau, for having taught me how to keep alive my macrophages and for the efficient collaboration in paper III. Robert, never give up: we will soon discover our IL-0 for the Nobel Price... if you think we manage with all statistics mess in our PhD journey, nothing would be impossible in life journey!

...Sandra Hellberg, for your sympathetic, enjoyable and funny friendship. You and Judit were the first people I have met at AIR from the beginning and you have always supported me in all period I was in Sweden, making me always feel at home and closer to the Swedish traditions, which I have always appreciated so much. I will never forget during my first Christmas time in Linköping (the coldest in the last 20 years!) our trip to Gamla Linköping for the Santa Lucia day: it is one of the nicest memories I had in Sweden for the typical snowy Christmas atmosphere. Thanks also for your support in all the PhD thesis defense steps.

...Emma Råsmark Røpke, for the special collaboration we had in paper II. It has been really challenging to work with you for your great clinical and research expertise in RPL field and for the nice friendly atmosphere we had during our collaboration. I will never forget our Italian time in Rome, spent in writing our paper and talking about our lives!

...Johanna Raffetseder, for having been a point of reference with her great expertise in research, both for notions and practical things for the last and crucial part of my PhD and for having supported me when all things seem to get more complicated with the warmth of a hot coffee and a chat with a sincere friend.

... Johanna Huoman, for having supported me with so many warmth hugs, which contribute to the really nice atmosphere I have always felt at AIR. Thanks for your precious support in research and for having shared with Johanna R. your room at work with me in these last years at the old building: it has been a really pleasure!

... Georgia Papapavlou, for sharing our challenging Greek-Latin friendship, by discovering all traditions which links these two ancient cultures. I will never forget our long chatting and our mutual support for research and life and your sincere enthusiasm give off by a big hug at 2018 ESRI Gala Dinner: in this occasion, I will never forget you were absolutely convinced about my capacities from the beginning, more than me! 
...Marie Rubér, for the great and forbearing support in paper II data analysis and for making me know about all Swedish food traditional days: you contribute to really make me feel closer to Swedish culture and traditions.

...Petra Cassel, Lina Wirestam, Helena Enocsson, Linda Fryland, Karin Söderman, Camilla Janefjord, Klara Martinsson, Maria Svenvik, Jonas Wetterö, Christina Ekerfelt and all people I have met at AIR for the really rare, precious, extremely cooperative, nice atmosphere at work, which I never felt anywhere else.

...Martina Berglund, Anders Ringqvist and their family, with Lena Sundling, who have welcomed me as a member of the family, giving me all different kinds of support and making me feel at home.

\section{For all these reasons and memories mentioned above, I really thank all colleagues, friends, professors at AIR, because this place in Sweden has really become for me a second Home...}

Thanks to...

Enrico Vizza, and all my collegues from the National Cancer Institute in Rome, Giuseppe Vocaturo, Cristina Vincenzoni, Giuseppe Cutillo, Emanuela Mancini, Ermelinda Baiocco, Benito Chiofalo, Rosanna Mancari and Giacomo Corrado, to always support me in these first nearly three years as Specialist in Obs/Gyn. 


\section{Thanks to...}

...my dad, who has taught me with his life and enthusiasm and pushed me to travel, not only for work and research, but also for my personal growth, making me understand that physically travelling you will make the greatest journey you would ever have done in yourself, discovering all your strengths and skills...

... and my mam, who has always remembered me to sow the pretext to always come back home

...my sister, who has always guided me in all my travels, from not only a practical but also and especially a conceptual and abstract point of view: I would have been lost in my travels without her patient and unlimited support...

... and Manuel to always bother her!

...all my family, my Grandma, Giuseppina, my uncles, Zia Vera, Zia Maria $e$ Salvo, Zia Rachele ed Angelo, and my cousins, Stefania $e$ Claudia, with Francesco $e$ Salvo and the little Aurora $e d$ Alberto, who have always been proud of me for my clinical and research work, even if it means I have not spent so much time with them in Sicily in these last years...

...Paolo, for simply having supporting me in every single day of my private and professional life in these years: nothing of this thesis and day will be possible without his love, patient and care for me...

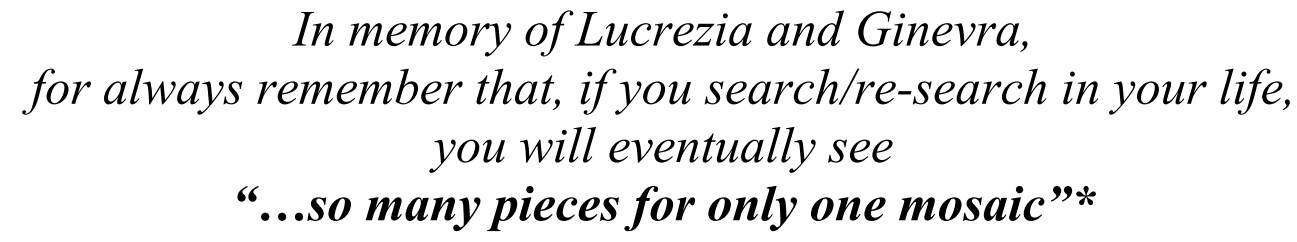

* "Atto di fede" Lyrics, Luciano Ligabue 


\section{References}

1) RECURRENT PREGNANCY LOSS Guideline of the European Society of Human Reproduction and Embryology. ESHRE Early Pregnancy Guideline Development Group. NOVEMBER 2017.

2) A.M. Kolte, L.A. Bernardi, O.B. Christiansen, S. Quenby, R.G. Farquharson, M. Goddijn, and M.D. Stephenson on behalf of the ESHRE Special Interest Group, Early Pregnancy. Terminology for pregnancy loss prior to viability: a consensus statement from the ESHRE early pregnancy special interest group. Human Reproduction, Vol.30, No.3 pp. 495-498, 2015

3) The Investigation and Treatment of Couples with Recurrent First- trimester and Second-trimester. Miscarriage. Green-top Guideline No. 17. April 2011

4) Practice Committee of American Society for Reproductive Medicine. Definitions of infertility and recurrent pregnancy loss: a committee opinion. Fertil Steril. 2013 Jan;99(1):63

5) Practice Committee of American Society for Reproductive Medicine. Evaluation and treatment of RPL: a committee opinion. Fertil Sterl. 2013; 98(5):1103-11

6) Jaslow CR, Carney JL, Kutteh WH: Diagnostic factors identified in $\mathbf{1 0 2 0}$ women with two versus three or more recurrent pregnancy losses. Fertil. Steril., 2010 vol.93(4) pp. 1234-43

7) Kolte AM, van Oppenraaij RH, Quenby S, Farquharson RG, Stephenson M, Goddijn M, Christiansen OB; ESHRE Special Interest Group Early Pregnancy. Non-visualized pregnancy losses are prognostically important for unexplained recurrent miscarriage. Hum Reprod 2014; 29:931-937

8) Van den Boogaard E, Cohn DM, Korevaar JC, Dawood F, Vissenberg R, Middeldorp S, Goddijn M, Farquharson RG et al. Number and sequence of preceding miscarriages and maternal age for the prediction of antiphospholipid syndrome in women with recurrent miscarriage. Fertil Steril 2013;99:188 - 192. 9) Coomarasamy A, Williams H, Truchanowicz E, Seed PT, Small R, Quenby S, Gupta P, Dawood F, Koot YEM, Bender-Atik R et al. A randomized trial of progesterone in women with recurrent miscarriage. N Engl J Med 2015; 373:2141 - 2148.

10) Chen T, Darrasse-Jeze G, Bergot AS, Courau G, Valdivia K, Strominger JL, Ruocco MG, Chaouat G, Klatzmann D. Self-specific memory regulatory T cells protect embryos at implantation in mice. J Immunol 2013; 191:2273 - 2281.

11) Kwiatek M, Geca T, Krzyanowski A, Malec A, Kwasniewska A. Peripheral dendritic cells and CD4+ CD25+Foxp3+ regulatory $T$ cells in the first trimester of normal pregnancy and in women with recurrent miscarriage. PLoS One 2015;6:e0124747

12) Southcombe $\mathrm{JH}^{1}$, Mounce $\mathrm{G}^{2}$, McGee $\mathrm{K}^{1}$, Elghajiji $\mathrm{A}^{1}$, Brosens $\mathrm{J}^{3,4}$, Quenby $\mathrm{S}^{3,4}$, Child $\mathrm{T}^{2}$, Granne $\mathrm{I}^{2}$ An altered endometrial CD8 tissue resident memory $\mathbf{T}$ cell population in recurrent miscarriage. ${ }^{\mathrm{S}} \mathrm{ci}$ Rep. 2017 Jan 23;7:41335. doi: $10.1038 /$ srep41335.

13) Human Reproduction, Vol.31, No.11 pp. 2428- 2434, 2016 Recurrent pregnancy loss: what is the impact of consecutive versus non-consecutive losses? P. Egerup, A.M. Kolte, E.C. Larsen, M. Krog, H.S. Nielsen, and O.B. Christiansen

14) Piosik ZM1, Goegebeur Y, Klitkou L, Steffensen R, Christiansen OB. Plasma TNF- $\alpha$ levels are higher in early pregnancy in patients with secondary compared with primary recurrent miscarriage. Am J Reprod Immunol. 2013 Nov;70(5):34758. doi: 10.1111/aji.12135. Epub 2013 May 9.

15) Michael Feichtinger, M.D.,a,b Elisabeth Wallner, M.Sc.,b Beda Hartmann, M.D.,c Angelika Reiner, M.D.,d and Thomas Philipp, M.D.c Transcervical embryoscopic and cytogenetic findings reveal distinctive differences in primary and secondary recurrent pregnancy loss Fertility and Sterility ${ }^{\circledR}$ Vol. 107, No. 1, January 2017

16) Kruse $C$, Steffensen R, Varming $K$, Christiansen OB. A study of HLA- DR and -DQ alleles in 588 patients and 562 controls confirms that HLA- DRB1*03 is associated with recurrent miscarriage. Hum Reprod 2004;19:1215-21. 
17) Nielsen HS, Steffensen R, Varming K, van Halteren AG, Spierings E, Ryder LP, et al. Association of HY-restricting HLA class II alleles with pregnancy outcome in patients with recurrent miscarriage subsequent to a firstborn boy. Hum Mol Genet 2009;18:1684-91.

18) Christiansen OB, Kolte AM, Dahl M, Larsen EC, Steffensen R, Nielsen HS, et al. Maternal homozygocity for a 14 base pair insertion in exon 8 of the HLA-G gene and carriage of HLA class II alleles restricting HY immunity predispose to unexplained secondary recurrent miscarriage and low birth weight in children born to these patients. Hum Immunol 2012;73:699-705.

19) Efrat Shapira1, Ronit Ratzon2, Ilana Shoham- Vardi2, Ruslan Serjienko2, Moshe Mazor1 and Asher Bashiri1. Primary vs. secondary recurrent pregnancy loss - epidemiological characteristics, etiology, and next pregnancy outcome. J. Perinat. Med. 40 (2012) 389-396

20) Christiansen OB, Steffensen R, Nielsen HS, Varming K. Multifactorial etiology of recurrent miscarriage and its scientific and clinical implications. Gynecol Obstet Invest 2008;66:257-67.

21) Gellersen B, Brosens IA, Brosens JJ. Decidualization of the human endometrium: mechanisms, functions, and clinical perspectives. Semin Reprod Med. 2007 Nov;25(6):445-53

22) Verma S, Hiby SE, Loke YW, King A. Human decidual natural killer cells express the receptor for and respond to the cytokine interleukin 15. Biol Reprod. 2000 Apr;62(4):959-68.

23) Dimitriadis E, White CA, Jones RL, Salamonsen LA. Cytokines, chemokines and growth factors in endometrium related to implantation. Hum Reprod Update. 2005 Nov-Dec;11(6):613-30

24) Achache H, Revel A. Endometrial receptivity markers, the journey to successful embryo implantation. Hum Reprod Update. 2006 Nov-Dec;12(6):731-46

25) Judit Svensson-Arvelund et al. The Human Fetal Placenta Promotes Tolerance against the Semiallogeneic Fetus by Inducing Regulatory T Cells and Homeostatic M2 Macrophages. J Immunol 2015; 194:1534-1544

26) Svensson-Arvelund, J. et al. Placenta in toxicology. Part II: Systemic and local immune adaptations in pregnancy. Toxicol. Pathol. 42, 327-38 (2014).

27) Svensson-Arvelund, J. \& Ernerudh, J. The Role of Macrophages in Promoting and Maintaining Homeostasis at the Fetal-Maternal Interface. Am. J. Reprod. Immunol. 74, 100-9 (2015).

28) Ernerudh, J., Berg, G. \& Mjösberg, J. Regulatory T helper cells in pregnancy and their roles in systemic versus local immune tolerance. Am. J. Reprod. Immunol. 66(Suppl 1), 31-43 (2011).

29) Gustafsson, C. et al. Gene expression profiling of human decidual macrophages: evidence for immunosuppressive phenotype. PLoS One 3, e2078 (2008).

30) Svensson, J. et al. Macrophages at the fetal- maternal interface express markers of alternative activation and are induced by M-CSF and IL-10. J. Immunol. 187, 3671-82 (2011).

31) Mjösberg, J., Berg, G., Jenmalm, M. C. \& Ernerudh, J. FOXP3+regulatory T cells and T helper 1, T helper 2, and T helper 17 cells in human early pregnancy decidua. Biol. Reprod 82, 698-705 (2010).

32) Tilburgs, T., Claas, F. H. J. \& Scherjon, S. A. Elsevier Trophoblast Research Award Lecture: Unique properties of decidual $T$ cells and their role in immune regulation during human pregnancy. Placenta 31(Suppl), S82-6 (2010).

33) Jin, Y. et al. Original Article: e Role of TSP- 1 on Decidual Macrophages Involved in the Susceptibility to Unexplained Recurrent Spontaneous Abortion. Am. J. Reprod. Immunol 61, 253-260 (2009).

34) Wang, W.-J. et al. Increased prevalence of T helper 17 ( 17) cells in peripheral blood and decidua in unexplained recurrent spontaneous abortion patients. J. Reprod. Immunol. 84, 164-70 (2010). 
35) Quenby, S., Vince, G., Farquharson, R. \& Aplin, J. Recurrent miscarriage: a defect in nature's quality control? Hum. Reprod. 17, 1959-63 (2002).ù

36) Christiansen OB, Reproductive Immunology, Mol Immunol, 2013; 55:8-15.

37) Patrice Nancy, Elisa Tagliani, Chin-Siean Tay, Patrik Asp, David E. Levy and Adrian Erlebacher. Chemokine Gene Silencing in Decidual Stromal Cells Limits T Cell Access to the Maternal-Fetal Interface. Science; 2012, 336 (6086), 1317-1321.

38) Lund M, Kamper-Jorgensen M, Nielsen HS, Lidegaard O, Andersen AM, Christiansen OB. Prognosis for live birth in women with recurrent miscarriage: what is the best measure of success? Obstet Gynecol 2012;119:37-43

39) Gamliel M, Goldman-Wohl D, Isaacson B, et al. Trained memory of human uterine nk cells enhances their function in subsequent pregnancies. Immunity. 2018;48(5):951-962.

40) Rowe JH, Ertelt JM, Xin L, Way SS. Pregnancy imprints regulatory memory that sustains anergy to fetal antigen. Nature. 2012;490(7418):102-106.

41) Clifford K, Rai R, Regan L. Future pregnancy outcome in unexplained recurrent first trimester miscarriage. Hum Reprod. 1997;12(2):387-389.

42) Vlaanderen W. Is recurrent miscarriage a useful clinical concept? Acta Obstet Gynecol Scand. 2014;93(9):848-851.

43) Saravelos SH, Li TC. Unexplained recurrent miscarriage: how can we explain it? Hum Reprod. 2012;27(7):1882-1886

44) *V Bruno,* J Svensson-Arvelund, M Rubér, G Berg, E Piccione, MC Jenmalm, J Ernerudh "Effects of low molecular weight heparin on the polarization and cytokine profile of macrophages and T helper cells in vitro". Sci Rep. 2018 Mar $8 ; 8(1): 4166$

45) Fluhr H, Spratte J, Ehrhardt J, Steinmüller F, Licht P, Zygmunt M.Heparin and low-molecular-weight heparins modulate the decidualization of human endometrial stromal cells. FertilSteril. 2010 May 15;93(8):2581-7

46) Siobhan Quenby, Gill Vince, Roy Farquharson and John Aplin. Recurrent miscarriage: a defect in nature's quality control? Hum Reprod. 2002 Aug; 17(8):1959-63

47) Salker MS, Nautiyal J, Steel JH, Webster Z, Sućurović S, Nicou M, Singh Y, Lucas ES, Murakami K, Chan YW, James S, Abdallah Y, Christian M, Croy BA, Mulac-Jericevic B, Quenby S, Brosens JJ. Disordered IL-33/ST2 activation in decidualizing stromal cells prolongs uterine receptivity in women with recurrent pregnancy loss. PLoS One. 2012;7(12):e52252

48) Vitor H Pomin and Barbara Mulloy. Current structural biology of the heparin interactome. Current Opinion in Structural Biology. Volume 34, October 2015, Pages 17-25

49) Fengchun Ye, Ying Kuang, Shuo Chen, Chong Zhang, Yin Chen, Xin-Hui, Xing. Characteristics of low molecular weight heparin production by an ultrafiltration membrane bioreactor using maltose binding protein fused heparinase I. Biochemical Engineering Journal. Volume 46, Issue 2, 1 October 2009, Pages 193-198

50) Wan MX, Zhang XW, Torkvist L, Thorlacius H. Low molecular weight heparin inhibits tumor necrosis factor alphainduced leukocyte rolling. Inflammation Res. 2001;50:581-584

51) Hyslop S, de NG. Heparin, polycations, and atherosclerosis. Semin Thromb Hemost 1993; 19: 89-98.5

52) Nelson RM, Venot A, Bevilacqua MP, et al. Carbohydrate-protein interactions in vascular biology. Annu Rev Cell Dev Biol 1995; 11: 601-631.

53) Helene Hochart et al. Concentration-dependent roles for heparin in modifying liopolysaccharide-induced activation of mononuclear cells in whole blood. Thromb Haemost 2008; 99: 570-575 
54) Heinzelmann M, Bosshart H. Heparin binds to lipopolysaccharide (LPS)-binding protein, facilitates the transfer of LPS to CD14, and enhances LPS-induced activation of peripheral blood monocytes. J Immunol 2005; 174: 2280-2287

55) Hogasen AK, Abrahamsen TG. Heparin suppresses lipopolysaccharide-induced monocyte production of several cytokines, but simultaneously stimulates C3 production. Thromb Res 1995; 80: 179-184.

56) Attanasio M, Gori AM, Giusti B, et al. Cytokine gene expression in human LPS- and IFNgamma-stimulated mononuclear cells is inhibited by heparin. Thromb Haemost 1998; 79: 959-962

57) Gori AM, Attanasio M, Gazzini A, et al. Cytokine gene expression and production by human LPS-stimulated mononuclear cells are inhibited by sulfated heparin- like semi-synthetic derivatives. J Thromb Haemost 2004; 2: 16571662

58) Luley L, Schumacher A, Mulla MJ, Franke D, Leottge M, Fill Malfertheiner S, Tchaikovski SN, Costa S-D, Hoppe B, Abrahams VM, Zenclussen AC. Low molecular weight heparin modulates maternal immune response in pregnant women and mice with thrombophilia. Am J Reprod Immunol 2015; 73: 417-427

59) Gil Mor , Ingrid Cardenas, Vikki Abrahams, Seth Guller. Inflammation and Pregnancy: The Role of the Immune System at the Implantation Site. Ann N Y Acad Sci 2011, 1221 (1), 80-7

60) Shah NM, Edey LF, Imami N, Johnson MR. Human labour is associated with altered regulatory T cell function and maternal immune activation. Clin Exp Immunol (2019) doi:10.1111/cei.13384

61) Schober L, Radnai D, Schmitt E, Mahnke K, Sohn C, Steinborn A. Term and preterm labor: Decreased suppressive activity and changes in composition of the regulatory T-cell pool. Immunol Cell Biol (2012) doi:10.1038/icb.2012.33

62) Vassiliadis S, Ranella A, Papadimitriou L, Makrygiannakis A, Athanassakis I. Serum levels of pro- and antiinflammatory cytokines in non-pregnant women, during pregnancy, labour and abortion. Mediators Inflamm (1998) doi:10.1080/09629359891199

63) Veith GL, Rice GE. Interferon gamma expression during human pregnancy and in association with labour. Gynecol Obstet Invest (1999) doi:10.1159/000010165

64) Sun Q, Zhang XL. Research on apoptotic signaling pathways of recurrent spontaneous abortion caused by dysfunction of trophoblast infiltration. Eur Rev Med Pharmacol Sci. 2017

65) Brosens I, Pijnenborg R, Vercruysse L, Romero R. The "great Obstetrical Syndromes" are associated with disorders of deep placentation. American Journal of Obstetrics and Gynecology. 2011.

66) Wu S, Zhang H, Tian J, Liu L, Dong Y, Mao T. Expression of kisspeptin/GPR54 and PIBF/PR in the first trimester trophoblast and decidua of women with recurrent spontaneous abortion. Pathol Res Pract. 2014;

67) Li S, Zhai J, Liu J, Hong Y, Zhao W, Zhao A, et al. BMAL1 facilitates trophoblast migration and invasion via SP1DNMT1/DAB2IP pathway in recurrent spontaneous abortion. Oncotarget. 2017;

68) Zhang J, Mo HQ, Tian FJ, Zeng WH, Liu XR, Ma XL, et al. EIF5A1 promotes trophoblast migration and invasion via ARAF-mediated activation of the integrin/ERK signaling pathway. Cell Death Dis. 2018;

69) Tian FJ, Qin CM, Li XC, Wu F, Liu XR, Xu WM, et al. Decreased Stathmin-1 Expression Inhibits Trophoblast Proliferation and Invasion and Is Associated with Recurrent Miscarriage. Am J Pathol. 2015;

70) Wu F, Tian F, Zeng W, Liu X, Fan J, Lin Y, et al. Role of peroxiredoxin2 downregulation in recurrent miscarriage through regulation of trophoblast proliferation and apoptosis. Cell Death Dis. 2017;

71) Canda MT, Caglayan LD, Demir N, Ortaç R. Increased C4d and Bb immunoreactivity and decreased MBL immunoreactivity characterise first-time pathologic first-trimester miscarriage: a case-control study. J Obstet Gynaecol (Lahore). 2018; 
72) Wang Z, Liu M, Nie X, Zhang Y, Chen Y, Zhu L, et al. NOD1 and NOD2 control the invasiveness of trophoblast cells via the MAPK/p38 signaling pathway in human first-trimester pregnancy. Placenta. 2015;

73) Wang Y, Liu HZ, Liu Y, Wang HJ, Pang WW, Zhang JJ. Disordered p53-MALAT1 pathway is associated with recurrent miscarriage. Kaohsiung J Med Sci. 2019;

74) Ding J, Cheng Y, Zhang Y, Liao S, Yin T, Yang J. The miR-27a-3p/USP25 axis participates in the pathogenesis of recurrent miscarriage by inhibiting trophoblast migration and invasion. J Cell Physiol. 2019;

75) Li X, Ma XL, Tian FJ, Wu F, Zhang J, Zeng WH, et al. Downregulation of CCNA2 disturbs trophoblast migration, proliferation, and apoptosis during the pathogenesis of recurrent miscarriage. Am J Reprod Immunol. 2019

76) Ahn JH, Park HR, Park CW, Park DW, Kwak-Kim J. Expression of TWIST in the first-trimester trophoblast and decidual tissue of women with recurrent pregnancy losses. American Journal of Reproductive Immunology. 2017.

77) Unverdorben L, Haufe T, Santoso L, Hofmann S, Jeschke U, Hutter S. Prototype and chimera-type galectins in placentas with spontaneous and recurrent miscarriages. Int J Mol Sci. 2016

78) Dong X, Yang L, Wang H. miR-520 promotes DNA-damage-induced trophoblast cell apoptosis by targeting PARP1 in recurrent spontaneous abortion (RSA). Gynecol Endocrinol. 2017

79) Jin Y, Wang X, Xiao Y, Lv C, Ding C, Lin Q. The Role of TSP-1 on Decidual Macrophages Involved in the Susceptibility to Unexplained Recurrent Spontaneous Abortion. Am J Reprod Immunol 2009;61:253-60.

80) Kaufmann P, Mayhew TM, Charnock-Jones DS. Aspects of human fetoplacental vasculogenesis and angiogenesis. II. Changes during normal pregnancy. Placenta (2004) doi:10.1016/j.placenta.2003.10.009

81) Zygmunt M, Herr F, Münstedt K, Lang U, Liang OD. Angiogenesis and vasculogenesis in pregnancy. European Journal of Obstetrics and Gynecology and Reproductive Biology doi:10.1016/S0301-2115(03)00168-4

82) Burke SD, Barrette VF, Gravel J, Carter ALI, Hatta K, Zhang J, Chen Z, Leno-Durán E, Bianco J, Leonard S, et al. Uterine NK Cells, Spiral Artery Modification and the Regulation of Blood Pressure During Mouse Pregnancy. Am J Reprod Immunol (2010) doi:10.1111/j.1600-0897.2010.00818.x

83) Faas MM, de Vos P. Uterine NK cells and macrophages in pregnancy. Placenta (2017) doi:10.1016/j.placenta.2017.03.001

84) Yajun NI, Victor MAY, Braas K. Pregnancy augments uteroplacental vascular endothelial growth factor gene expression and vasodilator effects. Am J Physiol - Hear Circ Physiol (1997) doi:10.1152/ajpheart.1997.273.2.h938

85) Poole TJ, Finkelstein EB, Cox CM. The role of FGF and VEGF in angioblast induction and migration during vascular development. Dev Dyn (2001) doi:10.1002/1097-0177(2000)9999:9999<::AID-DVDY1087>3.0.CO;2-2

86) Bai SX, Wang YL, Qin L, Xiao ZJ, Herva R, Piao YS. Dynamic expression of matrix metalloproteinases (MMP-2, -9 and -14) and the tissue inhibitors of MMPs (TIMP-1, -2 and -3) at the implantation site during tubal pregnancy. Reproduction (2005) doi:10.1530/rep.1.00283

87) Tazzyman S, Niaz H, Murdoch C. Neutrophil-mediated tumour angiogenesis: Subversion of immune responses to promote tumour growth. Semin Cancer Biol (2013) doi:10.1016/j.semcancer.2013.02.003

88) Hanna J, Goldman-Wohl D, Hamani Y, Avraham I, Greenfield C, Natanson-Yaron S, Prus D, Cohen-Daniel L, Arnon TI, Manaster I, et al. Decidual NK cells regulate key developmental processes at the human fetal-maternal interface. Nat Med (2006) doi:10.1038/nm1452

89) Lewis CE, Pollard JW. Distinct role of macrophages in different tumor microenvironments. Cancer Res (2006) doi:10.1158/0008-5472.CAN-05-4005 
90) Vacca P, Chiossone L, Mingari MC, Moretta L. Heterogeneity of NK cells and other innate lymphoid cells in human and murine decidua. Front Immunol (2019) doi:10.3389/ fimmu.2019.00170

91) Le Bouteiller P, Bensussan A. Up-and-down immunity of pregnancy in humans. F1000Research (2017) 6:1216. doi:10.12688/f1000research.11690.1

92) Blois SM, Klapp BF, Barrientos G. Decidualization and angiogenesis in early pregnancy: Unravelling the functions of DC and NK cells. J Reprod Immunol (2011) doi:10.1016/j.jri.2010.11.002

93) Bruno A, Mortara L, Baci D, Noonan DM, Albini A. Myeloid Derived Suppressor Cells Interactions With Natural Killer Cells and Pro-angiogenic Activities: Roles in Tumor Progression. Front Immunol (2019) doi:10.3389/fimmu.2019.00771

94) Holtan SG, Creedon DJ, Haluska P, Markovic SN. Cancer and Pregnancy: Parallels in Growth, Invasion, and Immune Modulation and Implications for Cancer Therapeutic Agents. Mayo Clin Proc (2009) 84:985-1000. doi:10.1016/S00256196(11)60669-1

95) Gordon S, Plüddemann A, Martinez Estrada F. Macrophage heterogeneity in tissues: phenotypic diversity and functions. Immunol Rev. 2014 Nov;262(1):36-55

96) Ning F, Liu H, Lash GE. The role of decidual macrophages during normal and pathological pregnancy. Am J Reprod Immunol 2016; 75: 298-309

97) Chen S-J, Liu Y-L, Sytwu H-K. Immunologic Regulation in Pregnancy: From Mechanism to Therapeutic Strategy for Immunomodulation. Clin Dev Immunol (2012) 2012:1-10. doi:10.1155/2012/258391

98) Ghaebi M, Nouri M, Ghasemzadeh A, Farzadi L, Jadidi-Niaragh F, Ahmadi M, Yousefi M. Immune regulatory network in successful pregnancy and reproductive failures. Biomed Pharmacother (2017) 88:61-73. doi:10.1016/j.biopha.2017.01.016

99) Feyaerts D, Kuret T, Van Cranenbroek B, Van Der Zeeuw-Hingrez S, Van Der Heijden OWH, Van Der Meer A, Joosten I, Van Der Molen RG. Endometrial natural killer (NK) cells reveal a tissue-specific receptor repertoire. Hum Reprod (2018) doi:10.1093/humrep/dey001

100) Wegmann TG, Lin H, Guilbert L, Mosmann TR. Bidirectional cytokine interactions in the maternal-fetal relationship: is successful pregnancy a TH2 phenomenon? Immunol Today. 1993 Jul;14(7):353-6

101) Adar T, Grisaru-Granovsky S, Ben Ya'acov A, Goldin E, Bar-Gil Shitrit A. Pregnancy and the Immune System: General Overview and the Gastroenterological Perspective. Dig Dis Sci (2015) 60:2581-9. doi:10.1007/s10620-015-3683-Z

102) Figueiredo AS, Schumacher A. The T helper type 17/regulatory T cell paradigm in pregnancy. Immunology (2016) 148:13-21. doi:10.1111/imm.12595

103) Mor, G., Aldo, P. \& Alvero, A. B. The unique immunological and microbial aspects of pregnancy. Nat Rev Immunol 17, 469-482 (2017).

104) Abrahamsson, T. R., Sandberg Abelius, M., Forsberg, A., Björkstén, B. \& Jenmalm, M. C. A Th1/Th2-associated chemokine imbalance during infancy in children developing eczema, wheeze and sensitization. Clin. Exp. Allergy 41, 1729-1739 (2011).

105) Henningsson, A. J., Tjernberg, I., Malmvall, B. E., Forsberg, P. \& Ernerudh, J. Indications of Th1 and Th17 responses in cerebrospinal fluid from patients with Lyme neuroborreliosis: A large retrospective study. J. Neuroinflammation 8 , 36 (2011).

106) Griffith, J. W., Sokol, C. L. \& Luster, A. D. Chemokines and chemokine receptors: positioning cells for host defense and immunity. Annu Rev Immunol 32, 659-702 (2014). 
107) Ekman, A. K. et al. Systemically elevated Th1-, Th2- and Th17-associated chemokines in psoriasis vulgaris before and after ultraviolet B treatment. Acta Derm. Venereol. 93, 525-531 (2013).

108) Annunziato, F., Cosmi, L., Liotta, F., Maggi, E. \& Romagnani, S. Defining the human T helper 17 cell phenotype. Trends Immunol. 33, 505-512 (2012).

109) Mantovani, A. et al. The chemokine system in diverse forms of macrophage activation and polarization. Trends Immunol. 25, 677-686 (2004).

110) Zhu, J. \& Paul, W. E. CD4 T cells: fates, functions, and faults. Blood 112, 1557-1569 (2008).

111) Qin, S. et al. The chemokine receptors CXCR3 and CCR5 mark subsets of $T$ cells associated with certain inflammatory reactions. J. Clin. Invest. 101, 746-754 (1998).

112) Islam, S. A. \& Luster, A. D. T cell homing to epithelial barriers in allergic disease. Nat. Med. 18, 705-715 (2012).

113) Park, H. et al. A distinct lineage of CD4 T cells regulates tissue inflammation by producing interleukin 17. Nat. Immunol. 6, 1133-1141 (2005).

114) Piao, H. L. et al. The CXCL12/CXCR4 axis is involved in the maintenance of Th2 bias at the maternal/fetal interface in early human pregnancy. Cell. Mol. Immunol. 9, 423-430 (2012).

115) Joseph, P. R. B., Sawant, K. V. \& Rajarathnam, K. Heparin-bound chemokine CXCL8 monomer and dimer are impaired for CXCR1 and CXCR2 activation: implications for gradients and neutrophil trafficking. Open Biol. 7, 170168 (2017).

116) P. Nancy and A. Erlebacher. T cell behavior at the maternal-fetal interface. Int. J. Dev. Biol. 58: 189-198 (2014)

117) Bai XX, Kong BH, Zhang YZ, Qu X, Wang HL. Expression and significance of chemokine CXC receptor 3, 4 and their ligands at the early pregnancy decidua and villi. Zhonghua fu chan ke za zhi. 2008;43(12):904-8.

118) Han J, Gu MJ, Yoo I, Choi Y, Jang H, Kim M, et al. Analysis of cysteine-X-cysteine motif chemokine ligands 9, 10, and 11, their receptor CXCR3, and their possible role on the recruitment of immune cells at the maternal-conceptus interface in pigs. Biol Reprod. 2017;97(1):69-80.

119) Ip, W. K., Wong, C. K. \& Lam, C. W. K. Interleukin (IL)-4 and IL-13 up-regulate monocyte chemoattractant protein1 expression in human bronchial epithelial cells: involvement of p38 mitogen-activated protein kinase, extracellular signal-regulated kinase 1/2 and Janus kinase-2 but not c-Jun NH2. Clin. Exp. Immunol 145, 162-172 (2006).

120) Sierra-Filardi, E. et al. CCL2 shapes macrophage polarization by GM-CSF and M-CSF: identification of CCL2/CCR2-dependent gene expression profile. J. Immunol. 192, 3858-67 (2014).

121) Lissauer, D., Goodyear, O., Khanum, R., Moss, P. A. H. \& Kilby, M. D. Profile of maternal CD4 T-cell effector function during normal pregnancy and in women with a history of recurrent miscarriage. Clin. Sci. (Lond). 126, 347-54 (2014).

122) Hills, F. A. et al. Heparin prevents programmed cell death in human trophoblast. Mol. Hum. Reprod. 12, 237-43 (2006).

123) Stenqvist, A.-C., Nagaeva, O., Baranov, V. \& Mincheva-Nilsson, L. Exosomes secreted by human placenta carry functional Fas ligand and TRAIL molecules and convey apoptosis in activated immune cells, suggesting exosomemediated immune privilege of the fetus. J. Immunol. 191, 5515-23 (2013).

124) Ikeda, T. et al. Dual effects of TRAIL in suppression of autoimmunity: the inhibition of Th1 cells and the promotion of regulatory T cells. J. Immunol. 185, 5259-67 (2010). 
125) Di Simone, N. et al. Low-molecular weight heparin induces in vitro trophoblast invasiveness: role of matrix metalloproteinases and tissue inhibitors. Placenta 28, 298-304 (2007).

126) Tersigni, C. et al. In vitro evidences of heparin's effects on embryo implantation and trophoblast development. Reprod. Sci. 19, 454-62 (2012).

127) Urman, B. et al. Luteal phase empirical low molecular weight heparin administration in patients with failed ICSI embryo transfer cycles: a randomized open-labeled pilot trial. Hum. Reprod. 24, 1640-7 (2009).

128) Pasquier, E. et al. Enoxaparin for prevention of unexplained recurrent miscarriage: a multicenter randomized double-blind placebocontrolled trial. Blood 125, 2200-5 (2015).

129) Pease JE, Williams TJ. Chemokines and their receptors in allergic disease. J Allergy Clin Immunol. 2006 Aug;118(2):305-18; quiz 319-20.

(130) Arck, P. C. Stress and immune mediators in miscarriage. Hum. Reprod. 16, 1505-1511 (2001).

(131) Stray-Pedersen, B. \& Stray-Pedersen, S. Etiologic factors and subsequent reproductive performance in 195 couples with a prior history of habitual abortion. Am. J. Obstet. Gynecol. 148, 140-146 (1984).

(132) Clifford, K., Rai, R. \& Regan, L. Future pregnancy outcome in unexplained recurrent first trimester miscarriage. Hum Reprod 12, 387-389 (1997).

(133) Mor, G., Aldo, P. \& Alvero, A. B. The unique immunological and microbial aspects of pregnancy. Nat Rev Immunol 17, 469-482 (2017).

(134) Jenkins, C. et al. Evidence of a T(H) 1 type response associated with recurrent miscarriage. Fertil. Steril. 73, 12061208 (2000).

(135) Raghupathy, R. et al. Maternal Th1- and Th2-type reactivity to placental antigens in normal human pregnancy and unexplained recurrent spontaneous abortions. Cell. Immunol. 196, 122-130 (1999).

(136) Boij, R. et al. Biomarkers of Coagulation, Inflammation, and Angiogenesis are Independently Associated with Preeclampsia. Am. J. Reprod. Immunol. 68, 258-270 (2012).

(137) Szarka, A., Rigo, J. Jr., Lazar, L., Beko, G. \& Molvarec, A. Circulating cytokines, chemokines and adhesion molecules in normal pregnancy and preeclampsia determined by multiplex suspension array. BMC Immunol 11, 59 (2010).

(138) Robertson, S. A., Chin, P. Y., Femia, J. G. \& Brown, H. M. Embryotoxic cytokines-Potential roles in embryo loss and fetal programming. J. Reprod. Immunol. 125, 80-88 (2018).

(139) Saito, S., Nakashima, A., Shima, T. \& Ito, M. Th1/Th2/Th17 and Regulatory T-Cell Paradigm in Pregnancy. Am. J. Reprod. Immunol. 63, 601-610 (2010).

(140) Robertson, S. A., Care, A. S. \& Moldenhauer, L. M. Regulatory T cells in embryo implantation and the immune response to pregnancy. J Clin Invest 128, 4224-4235 (2018).

(141) Raghupathy, R. et al. Cytokine production by maternal lymphocytes during normal human pregnancy and in unexplained recurrent spontaneous abortion. Hum. Reprod. 15, 713-718 (2000).

(142) Hill, J., Polgar, K. \& Anderson, D. T-helper 1-type immunity to trophoblast in women with recurrent spontaneous abortion. Jama 273, 1933-1936 (1995).

(143) Sehmsdorf, U. S. et al. Human miscarriage is associated with increased number of CD26+ decidual lymphocytes. Scand. J. Immunol. 59, 400-407 (2004). 
(144) Makhseed, M. et al. Th1 and Th2 cytokine profiles in recurrent aborters with successful pregnancy and with subsequent abortions. Hum. Reprod. 16, 2219-2226 (2001).

(145) Zenclussen, A. C. et al. Upregulation of decidual P-Selectin expression is associated with an increased number of Th1 cell populations in patients suffering from spontaneous abortions. Cell. Immunol. 213, 94-103 (2001).

(146) Rasmark Roepke, E. et al. Treatment efficacy for idiopathic recurrent pregnancy loss - a systematic review and meta-analyses. Acta Obs. Gynecol Scand 97, 921-941 (2018).

(147) Vento-Tormo R, Efremova M, Botting RA, Turco MY, Vento-Tormo M, Meyer KB, et al. Single-cell reconstruction of the early maternal-fetal interface in humans. Nature. 2018 Nov 14;563(7731):347-53.

(148) Sasaki Y, Sakai M, Miyazaki S, Higuma S, Shiozaki A, Saito S. Decidual and peripheral blood CD4 +CD25 + regulatory $\mathbf{T}$ cells in early pregnancy subjects and spontaneous abortion cases. Mol Hum Reprod. 2004 May;10(5):34753.

(149) Bruno V, Ticconi C, Sarta S, Piccione E, Pietropolli A. What has to be pointed out in unexplained recurrent pregnancy loss research in the unsolved fields: lessons from clinic. An Italian RPL Unit experience. Ital J Gynaecol Obstet. 2019;31(N. 2).

(150) Ticconi C, Giuliani E, Sorge R, Patrizi L, Piccione E, Pietropolli A. Gestational age of pregnancy loss in women with unexplained recurrent miscarriage. J Obstet Gynaecol Res. 2016 Mar;42(3):239-45.

(151) Gamliel M, Goldman-Wohl D, Isaacson B, Gur C, Stein N, Yamin R, et al. Trained Memory of Human Uterine NK Cells Enhances Their Function in Subsequent Pregnancies. Immunity. 2018 May 15;48(5):951-962.e5.

(152) Rowe JH, Ertelt JM, Xin L, Way SS. Pregnancy imprints regulatory memory that sustains anergy to fetal antigen. Nature. 2012 Oct 4;490(7418):102-6.

(153) Wegmann TG, Lin H, Guilbert L, Mosmann TR. Bidirectional cytokine interactions in the maternal-fetal relationship: is successful pregnancy a TH2 phenomenon? Immunology Today. 1993 Jul;14(7):353-6.

(154) Hanna N, Hanna I, Hleb M, Wagner E, Dougherty J, Balkundi D, et al. Gestational Age-Dependent Expression of IL-10 and Its Receptor in Human Placental Tissues and Isolated Cytotrophoblasts. J Immunol. 2000 Jun 1;164(11):57218 .

(155) Hsieh MY, Chen WY, Jiang MJ, Cheng BC, Huang TY, Chang MS. Interleukin-20 promotes angiogenesis in a direct and indirect manner. Genes Immun. 2006 Apr;7(3):234-42.

(156) Gao W, Thompson L, Zhou Q, Putheti P, Fahmy TM, Strom TB, et al. Treg versus Th17 lymphocyte lineages are cross-regulated by LIF versus IL-6. Cell Cycle. 2009 May 1;8(9):1444-50.

(157) Chang Y, De Nadai P, Azzaoui I, Morales O, Delhem N, Vorng H, et al. The chemokine CCL18 generates adaptive regulatory T cells from memory CD4+ T cells of healthy but not allergic subjects. FASEB J. 2010 Dec;24(12):5063-72.

(158) Griffith JW, Sokol CL, Luster AD. Chemokines and chemokine receptors: positioning cells for host defense and immunity. Annu Rev Immunol. 2014;32:659-702.

(159) Morales Prieto DM, Markert UR. MicroRNAs in pregnancy. J Reprod Immunol. 2011 Mar;88(2):106-11.

(160) Herrera-Van Oostdam AS, Toro-Ortíz JC, López JA, Noyola DE, García-López DA, Durán-Figueroa NV, MartínezMartínez E, Portales-Pérez DP, Salgado-Bustamante M, López-Hernández Y. Placental exosomes isolated from urine of patients with gestational diabetes exhibit a differential profile expression of microRNAs across gestation. Int $\mathrm{J}$ Mol Med. 2020 Aug;46(2):546-560. 


\section{Papers}

The papers associated with this thesis have been removed for copyright reasons. For more details about these see:

http://urn.kb.se/resolve?urn=urn:nbn:se:liu:diva-170492 


\section{FACULTY OF MEDICINE AND HEALTH SCIENCES}

Linköping University Medical Dissertations No. 1737, 2020

Clinical Immunology \& Obstetrics and Gynecology

Department of Biomedical and Clinical Sciences (BKV)

Linköping University

SE-581 83 Linköping, Sweden

www.liu.se 